\title{
Climate change in the Tahoe basin: regional trends, impacts and drivers
}

\section{Robert Coats}

Received: 26 September 2008 / Accepted: 25 August 2009 / Published online: 22 April 2010

(C) The Author(s) 2010. This article is published with open access at Springerlink.com

\begin{abstract}
The purpose of this study was to quantify the decadal-scale time trends in air temperature, precipitation phase and intensity, spring snowmelt timing, and lake temperature in the Tahoe basin, and to relate the trends to large-scale regional climatic trends in the western USA. Temperature data for six long-term weather stations in the Tahoe region were analyzed for trends in annual and monthly means of maximum and minimum daily temperature. Precipitation data at Tahoe City were analyzed for trends in phase (rain versus snow), decadal standard deviation, and intensity of rainfall. Daily streamflow data for nine gaging stations in and around the Tahoe basin were examined for trends in snowmelt timing, by two methods, and an existing record for the temperature of Lake Tahoe was updated. The results for the Tahoe basin, which contrast somewhat with the surrounding region, indicate strong upward trends in air temperature, a shift from snow to rain, a shift in snowmelt timing to earlier dates, increased rainfall intensity, increased interannual variability, and continued increase in the temperature of Lake Tahoe. Two hypotheses are suggested that may explain why the basin could be warming faster than surrounding regions. Continued warming in the Tahoe basin has important implications for efforts to manage biodiversity and maintain clarity of the lake.
\end{abstract}

\section{Introduction}

On a global scale, the general pattern of climate change is by now well documented, and is no longer scientifically controversial (Oreskes 2004). At the regional and local

R. Coats

Department of Environmental Science and Policy, University of California, Davis, CA 95616, USA

R. Coats $(\varangle)$

2512 9th St., Ste. 7, Berkeley, CA 94710, USA

e-mail: rncoats@ucdavis.edu,coats@hydroikos.com 
scales, however, there is considerable variation in the rates of climate change and its hydrologic and ecological impacts (Cohen 1990).

Lake Tahoe is a large ultra-oligotrophic lake lying at an elevation of 1,898 $\mathrm{m}$ in the central Sierra Nevada on the California-Nevada border (Fig. 1). The lake is renowned for its deep blue color and clarity. Due to concerns about progressive eutrophication and loss of clarity, the lake has been studied intensively since the mid-

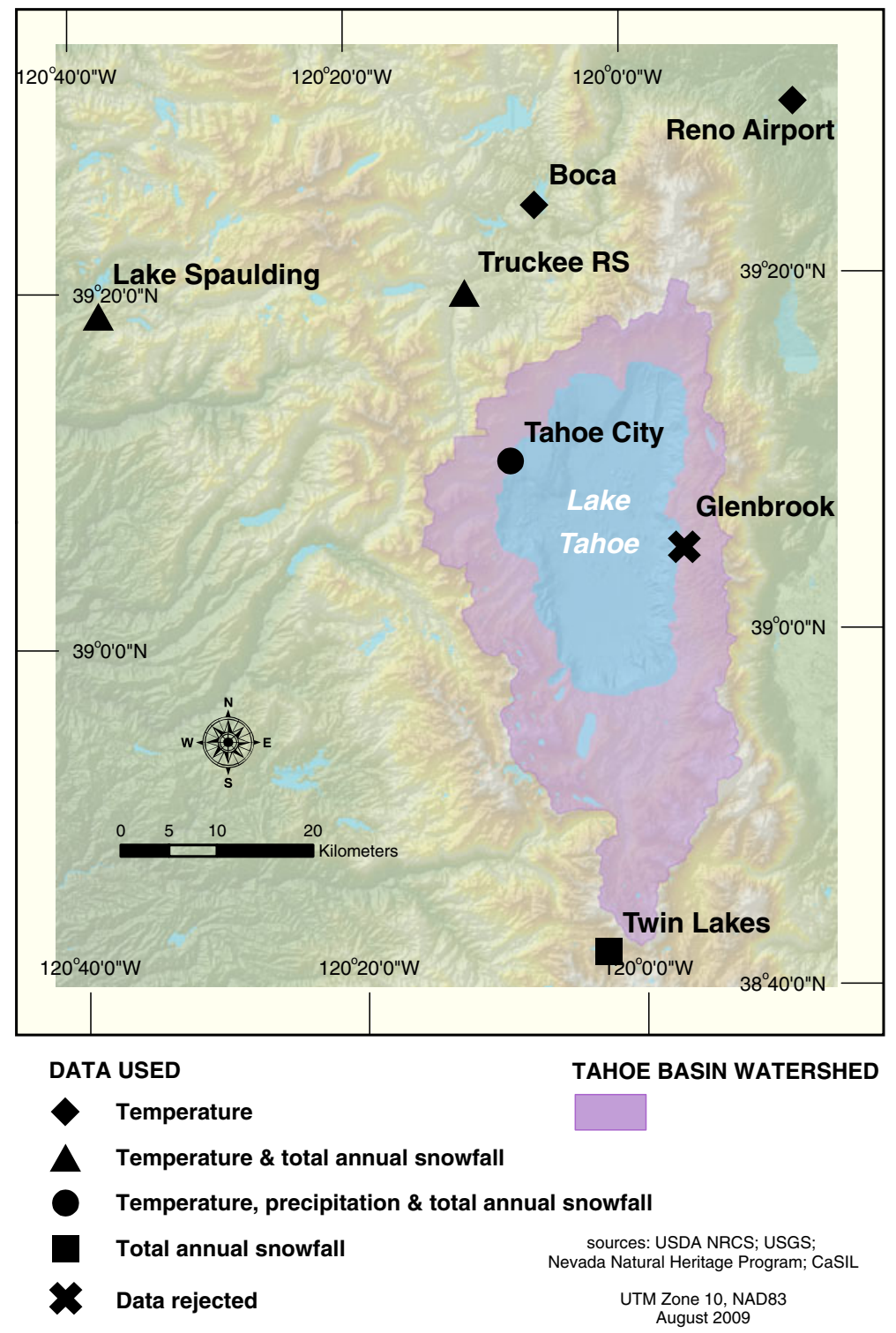

Fig. 1 Map of the Tahoe region, showing locations of weather stations used in this study 
1960s, and has been the focus of major efforts to halt the trends in clarity and trophic status. Previous work on the effects of climate change on the lake (Coats et al. 2006) has shown (1) that the lake is warming at an average rate of about $0.015^{\circ} \mathrm{C}$ year $^{-1}$; (2) the warming trend in the lake is driven primarily by increasing air temperature, and secondarily by increased downward long-wave radiation; (3) the warming trend on monthly and annual time scales is correlated with the Pacific decadal oscillation (PDO) and (to a lesser extent) with El Niño-southern oscillation (ENSO); (4) the warming of the lake is modifying its thermal structure, and increasing its resistance to deep mixing.

Recent work on climate change impacts in the western USA has focused attention on the shift in snowmelt timing toward earlier dates (Aguado et al. 1992; Dettinger et al. 2004; Cayan et al. 2001; Dettinger and Cayan 1995; Johnson et al. 1999; Stewart et al. 2005), the shift from snow to rain (Knowles et al. 2006; Regonda et al. 2005), the earlier onset of spring (Cayan et al. 2001); and the effect that these changes will have on water supply in California and throughout the western USA (Hamlet et al. 2005; Barnett et al. 2008; Mote et al. 2005). Pierce et al. (2008) showed that about half of the observed decline in western USA springtime snowpack (1950-1999) results from climate changes forced by anthropogenic greenhouse gases (GHGs), ozone and aerosols. In 2007, the catastrophic Angora Fire in the Tahoe basin showed how legacy vegetation changes can interact with climate change to increase fire hazard, and provided a stunning illustration of the increasing risk of wildfire in the western USA (Westerling et al. 2006; Running 2006; Brown et al. 2004).

Although these trends in climate are largely attributable to increasing atmospheric concentrations of GHGs (Bonfils et al. 2008a), recent modeling work has drawn attention to the role of soot (which is mostly black carbon, or BC) in modifying climate by reducing snow albedo. Hansen and Nazarenk (2004) showed that soot may reduce snow and ice albedo in Northern Hemisphere land areas by as much as $3 \%$, resulting in a climate forcing of $+0.3 \mathrm{~W} \mathrm{~m}^{-2}$. They found that due to positive feedbacks, the "efficacy" (change in air temperature per unit forcing) of soot is about twice that of $\mathrm{CO}_{2}$. Flanner et al. (2007), using a different model, found that the efficacy of $\mathrm{BC} /$ soot forcing is more than three times that of $\mathrm{CO}_{2}$, since the maximum forcing (due to aging of the snowpack and concentration of soot near the snow surface) coincides with the onset of snowmelt.

The purpose of this study is to document the long-term changes in temperature and precipitation in the Tahoe basin, place those changes in a regional context, and show how climate change is affecting watershed hydrology and the lake itself. A wide variety of issues related to water quality management, including the potential for invasion by exotic species, design of long-term and costly stormwater planning strategies, and restoration of stream environment zones all depend on a more complete understanding of the impact of climate change in the basin.

\section{Data sources and methods}

Analysis of climatic and hydrologic data in this study includes (a) annual average temperature trends at 6 stations, for the available periods of record; (b) trends in monthly averages of maximum $\left(T_{\max }\right)$ and minimum $\left(T_{\min }\right)$ daily temperature at 6 stations, 1956-2005; (c) trends in snowmelt timing at nine streamflow gages in and 
around the Tahoe basin; (d) the trend in the fraction of precipitation falling as snow at Tahoe City, 1910-2007; (e) the trend in exceedances of the 95th percentile daily rainfall amount at Tahoe City; (f) trends in the average annual and deseasonalized average daily temperature of Lake Tahoe; (g) the statistical relationships between local climatic variables and the PDO and ENSO. The climatic and hydrologic variables were selected for their likely importance to the future condition of Lake Tahoe.

\subsection{Air temperature}

Daily temperature (maximum, minimum and average), and precipitation data were obtained from the Western Regional Climate Center (WRCC 2008) for 16 stations within $35 \mathrm{~km}$ of Lake Tahoe, and screened for length and completeness of record. Of these, six stations (shown in Table 1) were selected for detailed analysis. Figure 1 shows the weather station locations, and the type of data used from each.

Three of the selected stations-Reno, Tahoe and Lake Spaulding-are part of the US Historical Climatology Network (HCN), with records through 2005 available online (Williams et al. 2008). For these stations, the monthly and annual precipitation records have been adjusted to remove the time-of-observation bias, "discontinuous inhomogeneities" resulting from station moves and changes in instrumentation, and effects of urbanization. The adjustment for inhomogeneities requires creating a difference series between a station and its neighbors, and using the Wilcoxon ranksum test to identify inhomogeneities and calculate adjustment parameters (Karl and Williams 1987).

The adjustment for the effects of urbanization is based on a power relationship (developed for the entire USA, for four seasons) between the urban-rural temperature difference and population, and uses census data to adjust the HCN monthly averages of $T_{\max }$ and $T_{\min }$ through 2005 (Karl et al. 1988). The urbanization effect at individual stations will of course vary from the regression-derived adjustment, and temperature trends from rapidly urbanizing areas must still be reviewed with caution. Comparing the raw monthly data with the "de-urbanized" data for Tahoe City shows an estimated maximum urbanization effect (by 2005) in the average temperature of $0.14^{\circ} \mathrm{C}$ in winter, $0.11^{\circ} \mathrm{C}$ in spring, and $0.16^{\circ} \mathrm{C}$ in summer and fall.

Table 1 Weather stations used in the analysis of regional trends

\begin{tabular}{lllllll}
\hline Station & $\begin{array}{l}\text { Coop } \\
\text { ID No. }\end{array}$ & Lat. & Long. & $\begin{array}{l}\text { Elev. } \\
(\mathrm{m})\end{array}$ & $\begin{array}{l}\text { Period of } \\
\text { record used }\end{array}$ & HCN? \\
\hline Reno & 266779 & $39^{\circ} 30^{\prime} \mathrm{N}$ & $119^{\circ} 47^{\prime} \mathrm{W}$ & 1,341 & $1889-2005$ & Yes \\
Boca & 040931 & $39^{\circ} 06^{\prime} \mathrm{N}$ & $120^{\circ} 06^{\prime} \mathrm{W}$ & 1,699 & $1937-2006$ & No \\
Truckee RS & 049043 & $39^{\circ} 20^{\prime} \mathrm{N}$ & $120^{\circ} 11^{\prime} \mathrm{W}$ & 1,829 & $1935-2006$ & No \\
Tahoe & 048758 & $39^{\circ} 10^{\prime} \mathrm{N}$ & $120^{\circ} 08^{\prime} \mathrm{W}$ & 1,900 & $1910-2005$ & Yes \\
Lake Spaulding & 044713 & $39^{\circ} 19^{\prime} \mathrm{N}$ & $120^{\circ} 38^{\prime} \mathrm{W}$ & 1,573 & $1914-2005$ & Yes \\
Sierra average, WRCC & - & - & - & - & $1895-2007$ & - \\
\hline
\end{tabular}

Data from the Glenbrook station (263205) were analyzed but discarded due to an effect of station relocation. WRCC refers to the Western Regional Climate Center, Reno, NV 
For the non-HCN stations (Boca, Truckee Ranger Station and Glenbrook), copies of the Station History Reports, were obtained from the National Climate Data Center, and reports from NOAA's Multi-Network Metadata System (National Climate Data Center 2008) were obtained on-line. These reports aided in interpretation of possible effects of station moves and bias introduced by changes in the time of observation.

In addition, monthly and annual averages of $T_{\max }$ and $T_{\min }$ for the Sierra region, 1895-2007 were obtained from the Western Regional Climate Center (2008). The Cooperative (coop) station data for the 21 Sierra stations from which the averages were derived have been screened for outliers, and values adjusted for inhomogeneities. The station are located between latitudes $36.48^{\circ} \mathrm{N}$ and $39.57^{\circ} \mathrm{N}$, longitudes $118.83^{\circ} \mathrm{W}$ and $121.93^{\circ} \mathrm{W}$, and elevations ranging from $397 \mathrm{~m}$ to $2140 \mathrm{~m}$.

The reported ground elevation of the Truckee Ranger Station (RS) weather station changed 4 times between, 1933 and, 1983, varying between $1824 \mathrm{~m}$ and $1835 \mathrm{~m}$, but the records show no change in latitude and longitude in this period (reported as $39.33333^{\circ} \mathrm{N}, 120.18330^{\circ} \mathrm{W}$ ). Beginning in 1991 , the location was reported as "Truckee RS Workyard", which is located $1.53 \mathrm{~km}$ southwest of the Ranger Station. In 2000 the weather station was apparently moved 700 m northeast, with the elevation remaining at 1,835 m. Both the Workyard and the Ranger Station are located on gently sloping to flat terrain, above the valley floor. In December 2006 the weather station was moved to the new Workyard location at an elevation of 1,775 m, near the Truckee River. This new location may be more influenced by cold air drainage and intense nighttime inversions than the previous locations, but data from the new location were not used here.

There is a gap in the Truckee RS data from, 1920-1934. During the period 19041919, the station was moved several times, and the $T_{\max }$ and $T_{\min }$ temperature records for that period show standard deviations more than twice those of the 1935-2006 period. The US Weather Bureau's Station History Report for 1920 characterized the record as "poor", and the station was closed. Data from the 1904-1920 period were not used in calculating annual average temperatures.

The time of observation at Truckee RS is not given in the station history reports, but the Forest Service staff has used a hygrothermograph as back-up for the max-min thermometer. Up to May $2007 T_{\max }$ and $T_{\min }$ were read from the chart trace when the thermometer could not be read at the designated time.

For Truckee RS, about $560 T_{\max }$ and $T_{\min }$ values were missing in the daily temperature record for the period 1956-2005. Of these, 520 were filled in by linear regression with records from nearby Donner Memorial State Park (5.3 km WSW; $R^{2}=0.95$ and 0.91 , and $\mathrm{SE}=2.1^{\circ} \mathrm{C}$ and $1.9^{\circ} \mathrm{C}$, respectively, for $T_{\max }$ and $\left.T_{\min }\right)$, and an additional 40 values were filled in by seasonal (winter, spring, summer, fall) regressions with the temperature record at Tahoe City $\left(18.5 \mathrm{~km} \mathrm{SSE}, R^{2}=0.82-0.93\right.$, $\left.\mathrm{SE}=1.6-2.7^{\circ} \mathrm{C}\right)$.

Since December, 1936 the Boca station has been located at the Bureau of Reclamation office, about $600 \mathrm{~m}$ south of the Boca Reservoir dam. The elevation decreased by $3 \mathrm{~m}$ in 1982, and is now at an elevation of 1,700 $\mathrm{m}$. The Station History Report does not give the time of observation. Boca holds the record for the lowest temperature ever recorded in California: $-45^{\circ} \mathrm{F}\left(-42.8^{\circ} \mathrm{C}\right)$ on January $20,1937$. 
The history of the Glenbrook station suggests possible problems in the data. From 1950 to 1972 , the station was located in a small saddle, about $500 \mathrm{~m}$ east of and $52 \mathrm{~m}$ above the lake. In 1972 it was moved about $250 \mathrm{~m}$ south, and $6 \mathrm{~m}$ higher. In 1975 it was moved to its present location $800 \mathrm{~m}$ south and $330 \mathrm{~m}$ east of its initial location, and $37 \mathrm{~m}$ above the lake. Furthermore, the first location was somewhat sheltered from direct wind off the lake by a small knoll to the west, whereas since 1972, the station has been more exposed to afternoon wind, and possibly to increased night-time cold air drainage. To complicate matters, the instrument type was changed from a max-min mercury thermometer to a digital maximum-minimum temperature system (MMTS) in 1983, which is currently located in a lawn that is irrigated twice daily during summer months. The time of observation was changed from 6:00 PM to 5:00 $\mathrm{PM}$ in 1960, and from 5:00 PM to 4:00 PM in 1975. Changes in the time of observation are known to introduce bias in a temperature record (Redmond 1991, 1992; Karl et al. 1986). In order to measure the consistency of long-term temperature records, I installed carefully-calibrated temperature loggers at the pre-1975 and present instrument sites, and measured temperature at 15 min intervals from early July to early September, 2008.

Preliminary plotting and inspection of the long-term trends showed upward trends in annual averages of $T_{\max }$ and/or $T_{\min }$ at most sites, but a cooling trend in maximum daily temperature from the mid-1930s to the mid-1950s at some sites. For this reason, the half-century period, 1956-2005, with its generally monotonic increases and more reliable data, was selected for detailed analysis of time trends in monthly average air temperature.

With the Glenbrook data discarded due to the possible effect of station relocation, I tested the annual averages of $T_{\max }$ and $T_{\min }$ over the available period of record for time trends, using the non-parametric Kendall trend test. This test is widely used for testing time trends in environmental variables; it has advantages over ordinary least squares (OLS) regression in that normality of the residuals is not required, and it is more resistant to leveraging by extreme events. (Helsel et al. 2005; Helsel and Frans 2006). The Kendall test calculates the "Theil slope" as the median of slopes of all possible lines between data pairs.

Time series data often show significant autocorrelation, which can increase the likelihood of rejecting the null hypothesis (that is, that there is no trend), when it should be accepted (von Storch 1999). To address this problem, I calculated $T_{0}$, the "time between effectively independent observations", using a simple approximation given by Trenberth (1984). Where necessary, I then "pruned" the data, discarding enough so that the time between observations was $\geq T_{0}$.

Using the same test, the annual series of monthly averages of $T_{\max }$ and $T_{\min }$ were tested for time trends at each of the five sites. As with the annual averages, I tested for serial correlation, and pruned the data where necessary. The monthly averages of $T_{\max }$ showed very little serial correlation, but most of the monthly averages of $T_{\min }$ for spring, summer and fall from Reno, Truckee and Tahoe City showed correlation coefficients exceeding 0.20 , with a $T_{0}$ of $1.5-2.5$ years.

It would be useful to know if the trends in monthly temperature are consistent across the region, and across months. I used the method given by van Belle and Hughes (1984) to test for homogeneity of trends between months, between sites, and for the interaction between sites and months in the trends. This nonparametric $\left(\chi^{2}\right)$ test uses $Z$ values from the Kendall test, and is formatted like an analysis of variance (ANOVA). 


\subsection{Precipitation and snowmelt}

The total snowfall water equivalent at Tahoe City was calculated for each year by summing the precipitation that occurred on days with average temperature below freezing. The slope of the time trend in snowfall as fraction of total annual precipitation was estimated (and its significance tested) using the Kendall test. Some modeling studies (e.g. Hamlet et al. 2005) have used thresholds at $-0.5^{\circ} \mathrm{C}$ and $+0.5^{\circ} \mathrm{C}$ for partitioning precipitation between rain and snow, with a linear change between the thresholds for days with mixed rain and snow. It seems unlikely, however, that this more nuanced approach would make much difference in the time trend.

An increase in the intensity of rainfall may be at least as important as a trend in the annual amount, especially with regard to erosion potential. Kim (2005) modeled the effect of increasing $\mathrm{CO}_{2}$ concentrations on the 95th percentile of daily rainfall in the northern Sierra, that is, the amount equaled or exceeded on $5 \%$ of the rainy days. In the relatively small watersheds of the Tahoe basin, the duration of rainfall that controls flood frequency is on a time scale of hours, and the largest floods are associated with rain-on-snow events. Unfortunately, hourly rainfall data for the basin are not available over a long enough time period to examine trends. To test for a time trend in daily rainfall intensity, I found the 95th percentile rainfall amount (19102007), and compared it to the 2-year annual maximum daily rainfall. I then counted the number of times per half-decade that the 95th percentile value is equaled or exceeded, and tested for a time trend with the Kendall test.

There are over 20 streamflow gages currently in operation in the Tahoe basin, but only five of these (with continuous or near-continuous records dating from 1972 or earlier) are useful for analyzing trends in snowmelt timing. These are the most downstream gages on Ward, Blackwood, Trout and Third Creeks, and the Upper Truckee River. For each station, I identified the date of the maximum discharge in April through July in the five streams, and then scrolled through the record for Blackwood Creek (the watershed with the highest mean annual precipitation) to find sharp runoff peaks that appeared to result from rainstorms. Two suspicious peaks were found and checked against rainfall in the Tahoe City record. The dates for these peaks at all stations were then replaced as needed by peaks not influenced by rainfall.

Since wet (heavy snowfall) years generally have later snowmelt peak timing (SMPT) than dry (low snowfall) years, I removed the effect of total annual snowfall with locally weighted scatterplot smoothing (LOWESS; Helsel and Hirsch 1995) of the plot of SMPT versus total annual snowfall, and then tested for time trends in the residuals, using the Kendall test (with data pruning where $T_{0}$ exceeded 1.5 years. I then averaged the Theil slopes of the time trend for the five streams, to estimate the average rate of shift in SMPT. I also tried total annual discharge as the ancillary variable, but it was not as effective as total annual snowfall, possibly because a shift from snow to rain is uncoupling the relationship between timing of the snowmelt and total annual precipitation.

For comparison of shift in SMPT for streams inside and outside of the Tahoe basin, I searched for nearby gaging stations outside of the Tahoe basin that are snow-dominated, have records at least as long as the Tahoe basin streams, and are relatively unaffected by dams and diversions. The stations best meeting these criteria are Sagehen Creek (north of Truckee), the South Fork Yuba River (east of Lake Spaulding), and the East and West Forks of the Carson River (south of the Tahoe 
basin). For total annual snowfall (the ancillary variable in the Kendall trend test), I used the Truckee record for Sagehen Creek, the Lake Spaulding record for the S. Fk. Yuba, and the record for twin lakes (coop ID no. 49105) for the Carson tributaries.

Four of the five Tahoe basin streams showed monotonic trends toward earlier SMPT, but Blackwood Creek, with unusually early snowmelt in the period 19611970, was an exception. Blackwood Canyon was subjected to much heavier logging during the 1950s and early 1960s than the other four watersheds, and it is possible that the opening of the forest canopy accelerated snowmelt, shifting it toward earlier dates. At the near-by Central Sierra Snow Laboratory, the rate of snowmelt over an entire melt season averaged $75 \%$ higher in a clearing than in the forest; in years with long-lasting snowpack, the average melt rate after May 1 was $25 \mathrm{~mm} \mathrm{day}^{-1}$ in the open vs.15 mm day ${ }^{-1}$ in the forest (Kattelmann 1991). Re-growth of the forest canopy in Blackwood Canyon could thus delay snowmelt, offsetting the effect of a warming trend. For this reason, the period 1961-1970 for Blackwood Creek was not considered in the analysis.

In $1960,10.5 \%$ of the catchment of Sagehen Creek upstream of the USGS gaging station was burned in the 45,000 ac Donner Ridge Fire (Johnson and Needham 1966). Reforestation and regrowth since then could have played a minor role in retarding snowmelt, although the fire was so intense in some areas that re-growth has been slow.

A number of studies on snowmelt timing in the West have used the "center timing", or date of the centroid of the annual hydrograph (Barnett et al. 2008; Stewart et al. 2005). This is calculated as the discharge-weighted mean day in the water year (WY), that is: CT $=\sum\left(\mathrm{t}_{\mathrm{i}} \mathrm{q}_{\mathrm{i}}\right) / \sum\left(\mathrm{q}_{\mathrm{i}}\right)$, where $t_{i}=$ the $i$ th day in the water year, and $q_{i}=$ discharge on the $i$ th day. To provide a basis for comparison with other regional studies, I calculated the annual CT for all nine gaging stations in the sample (both inside and outside of the basin).

\subsection{Lake temperature and thermal structure}

Previous calculations of average temperature of Lake Tahoe ran from December, 1969 to October 2002 (Coats et al. 2006). Using an identical methodology the record for the Lake was updated through August 2007. This included calculating the temperature at $400 \mathrm{~m}$, indices of lake stability, the volume-averaged daily lake temperature, the monthly average lake temperature, and the annual maximum, minimum and average lake temperature. The trend in the latter was tested with the Seasonal Kendall test, with data pruning where necessary.

\subsection{Influence of the Pacific decadal oscillation and El Niño/southern oscillation}

Several studies have shown that ocean circulation and temperature patterns, particularly the Pacific decadal oscillation (PDO) and El Niño/southern oscillation (ENSO) are statistically related to warming trends in the western USA (Arhonditsis et al. 2004; Mantua et al. 1997; LaDochy et al. 2007), the earlier onset of snowmelt runoff (Cayan et al. 2001; Dettinger and Cayan 1995; Stewart et al. 2005), the shift in precipitation from snow to rain (Knowles et al. 2006; Regonda et al. 2005), declining snowpacks (Mote et al. 2005; Hamlet et al. 2005), and earlier onset of spring (Cayan et al. 2001). To examine the relationship between these large-scale climatic 
Table 2 Local climatic and hydrologic variables tested by regression against the Pacific decadal oscillation (PDO) and mean ENSO index (MEI)

\begin{tabular}{|c|c|c|}
\hline Dependent variable & $\mathrm{PDO}$ & MEI \\
\hline $\begin{array}{l}\text { Monthly ave. of deseasonalized } \\
T_{\max } \text { and } T_{\min }\end{array}$ & Monthly values & Monthly values \\
\hline $\begin{array}{l}\text { April-June deseasonalized } \\
T_{\max } \text { and } T_{\min }(1914-2002)\end{array}$ & Apr-June monthly values & MARAPR-MAYJUN \\
\hline $\begin{array}{l}\text { Percent of annual water year (WY) } \\
\text { precip. as snow }\end{array}$ & Ave. of Nov-Mar values & Ave. of OCTNOV-FEBMAR \\
\hline Day of peak snowmelt discharge & Ave. of Apr-Jun values & Ave. of MARAPR-MAYJUN \\
\hline $\begin{array}{l}\text { Monthly ave. of deseasonalized daily } \\
\text { lake temp, lagged } 1,2 \text { and } 3 \text { months }\end{array}$ & Monthly values & Monthly values \\
\hline
\end{tabular}

Adjusted $P$ values were calculated from the pruned data set, to account for serial correlation (see Section 2.1)

descriptors and the dependent climate variables in the Tahoe basin, I used OLS regression to test (1) deseasonalized monthly average $T_{\max }$ and $T_{\min }$ air temperature at Tahoe City, (2) water year percent precipitation as snow; (3) SMPT, adjusted for total annual snowfall, and averaged over the five basin streams; and (4) monthly average of deseasonalized volume-averaged lake temperature. For the latter, lake temperature was lagged 1,2, and 3 months behind PDO and MEI, since the lake would not be expected to respond instantly to large-scale atmospheric and ocean temperature patterns.

Monthly values of the PDO were obtained from the Joint Institute for the Study of the Atmosphere and Ocean (JISAO 2008). For the ENSO, I used the bimonthly values of the Multivariate ENSO Index (NOAA 2008). Table 2 shows the explanatory dependent variables used in the tests. Since the PDO and MEI values are somewhat correlated $(r=0.57)$, simple multiple regression would not be helpful.

\section{Results}

\subsection{Air temperature trends}

The slope of the trends in $T_{\max }$ and $T_{\min }$ depends on the period of record, and varies with location. Figure 2a-f shows the time trends in annual averages at five stations, along with the regional average for the Sierra Region. Table 3 shows the results of the Kendall trend tests for significance of slopes. The adjusted $P$ values are based on the Kendall test using pruned data, to eliminate the "over-rejection" problem associated with serial correlation.

The strongest upward trends in annual averages over the available periods of record were in $T_{\max }$ at Reno, and $T_{\min }$ at Tahoe City. Truckee and Boca showed significant upward trends in both $T_{\max }$ and $T_{\min }$. At Lake Spaulding, there was no significant time trend in either $T_{\max }$ or $T_{\min }$ over the period of record (1914-2005).

The data from the temperature loggers installed at the pre- and post-1975 Glenbrook sites showed that $T_{\max }$ averaged $0.53^{\circ} \mathrm{C}$ cooler, and $T_{\min } 1.36^{\circ} \mathrm{C}$ cooler at the current site than at the pre-1975 site ( $\mathrm{P}$ by one-tailed paired $t$ tests $<10^{-7}$ ), for the period July 2 to September 5, 2008. The lower $T_{\max }$ is probably explained by lawn 

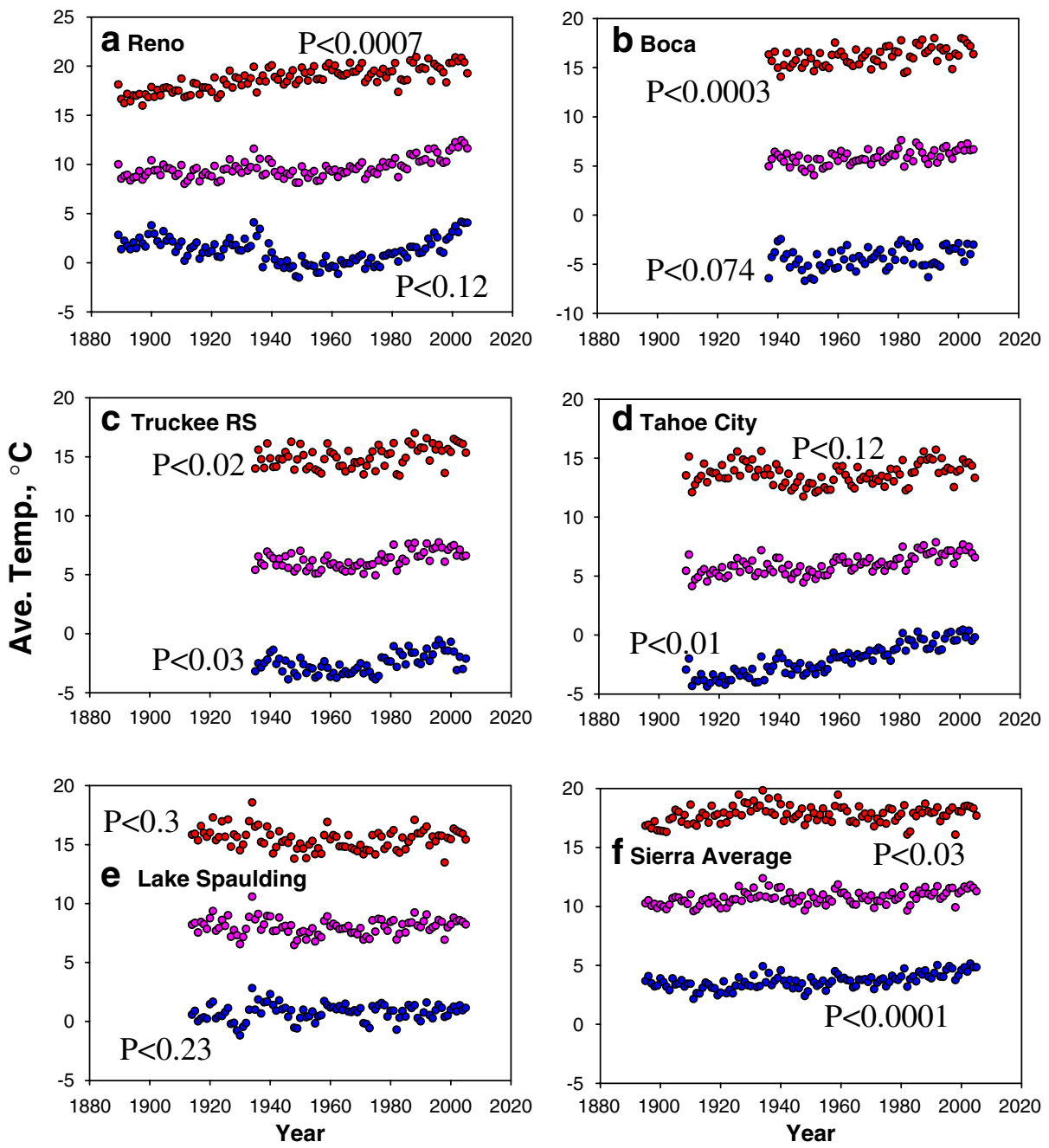

Fig. 2 Annual average air temperatures ( $T_{\max }[\mathrm{red}], T_{\text {ave }}[$ pink $]$ and $T_{\min }[$ blue $\left.]\right)$ at a Reno, 19892005; b Boca, 1935-2005; c Truckee Ranger Station, 1935-2006; d Tahoe City, 1909-2005; e Lake Spaulding, 1945-2005; and f average for Sierra Nevada, 1914-2005, from WRCC. See Table 3 for trend test results

irrigation, and the lower $T_{\min }$ by greater exposure to cold air drainage. The long-term record for Glenbrook is considered unusable.

Annual averages, however, may conceal some interesting differences in trends by month. Figure $3 \mathrm{a}-\mathrm{f}$ show the Theil slopes and significance level by month, at five stations (Reno, Boca, Truckee, Tahoe City and Lake Spaulding) along with the monthly slopes for the Sierra Region, for the period 1956-2005. As shown by the results of the test for homogeneity of trend slopes of these 5 stations (Table 4), for $T_{\min }$ there were highly significant differences among sites across months, and among months across sites, but there was no consistent month-site interaction. For $T_{\max }$, 
Table 3 Kendall trend test results on annual averages of $T_{\max }$ and $T_{\min }$, for period of record

\begin{tabular}{lcclc}
\hline Station & Corr. Coeff. & $\begin{array}{l}\text { Theil Slope } \\
\left({ }^{\circ} \mathrm{C} \mathrm{year}^{-1}\right)\end{array}$ & $P<$ & Adj. $P<$ \\
\hline For ann. ave. of $T_{\max }$ & & & & \\
$\quad$ Reno AP & 0.588 & 0.029 & 0.00005 & 0.0007 \\
Boca & 0.330 & 0.024 & 0.0001 & 0.0003 \\
Truckee RS & 0.252 & 0.018 & 0.0017 & 0.018 \\
Tahoe & 0.107 & 0.006 & 0.12 & - \\
Lake Spaulding & -0.075 & -0.003 & 0.289 & - \\
$\quad$ Sierra average & 0.139 & 0.005 & 0.017 & 0.030 \\
For ann. ave. of $T_{\min }$ & & & & - \\
Reno AP & -0.098 & -0.007 & 0.116 & 0.074 \\
Boca & 0.224 & 0.019 & 0.006 & 0.030 \\
Truckee RS & 0.273 & 0.018 & 0.0007 & 0.009 \\
Tahoe & 0.734 & 0.047 & 0.00005 & - \\
Lake Spaulding & 0.089 & 0.003 & 0.23 & 0.00005 \\
Sierra average & 0.438 & 0.012 & 0.00005 & \\
\hline
\end{tabular}

the trend slopes for months were heterogeneous when averaged across sites, but the trend slopes for sites were homogeneous when averaged over months, and there was no significant site-month interaction.

The strongest warming trends in the period 1956-2005 were in $T_{\min }$ at Reno and Tahoe, especially in summer months. These stations also showed some upward trends in $T_{\max }$, but these were not as strong as the trends in night-time temperature. At Truckee and Boca, both $T_{\max }$ and $T_{\min }$ trended upward, especially in winter and spring. In contrast to Reno and Tahoe, warming rates were lower in the summer and minimal in the fall. Lake Spaulding showed cooling trends in both $T_{\max }$ and $T_{\min }$ in December, but these are offset by increases in spring and summer in both $T_{\max }$ and $T_{\min }$.

\subsection{Precipitation and snowmelt timing}

Analysis of the precipitation and temperature records at Tahoe City (1910-2007) shows that the percent of total annual precipitation falling as snow (defined here as precipitation falling on a day with average temperature at or below freezing) is decreasing. Figure 4 shows the trend. The OLS regression slope is $-0.19 \%$ year $^{-1}$ and the Theil slope is $-0.18 \%$ year $^{-1}$, with $P<0.0004$ and insignificant serial correlation. Such a shift has important implications for erosion and sediment transport in the Tahoe basin, since these processes tend to be more active in a rainfall regime than in a snowfall regime.

The total annual precipitation at Tahoe City (1910-2007) seems to trend slightly upward, $\left(0.13 \mathrm{~cm} \mathrm{year}^{-1}\right)$ but the apparent trend is not statistically significant $(P<0.21)$. The interannual variability, however does seem to be increasing. For the decadal standard deviation, the tau correlation coefficient is 0.42 , with $P<$ 0.1 ), suggesting that wet years are getting wetter, and dry years getting drier. This has important implications for vegetation and soil erosion. Vegetation stressed (or burned) during drought years will provide less protection against soil erosion during wet years. 

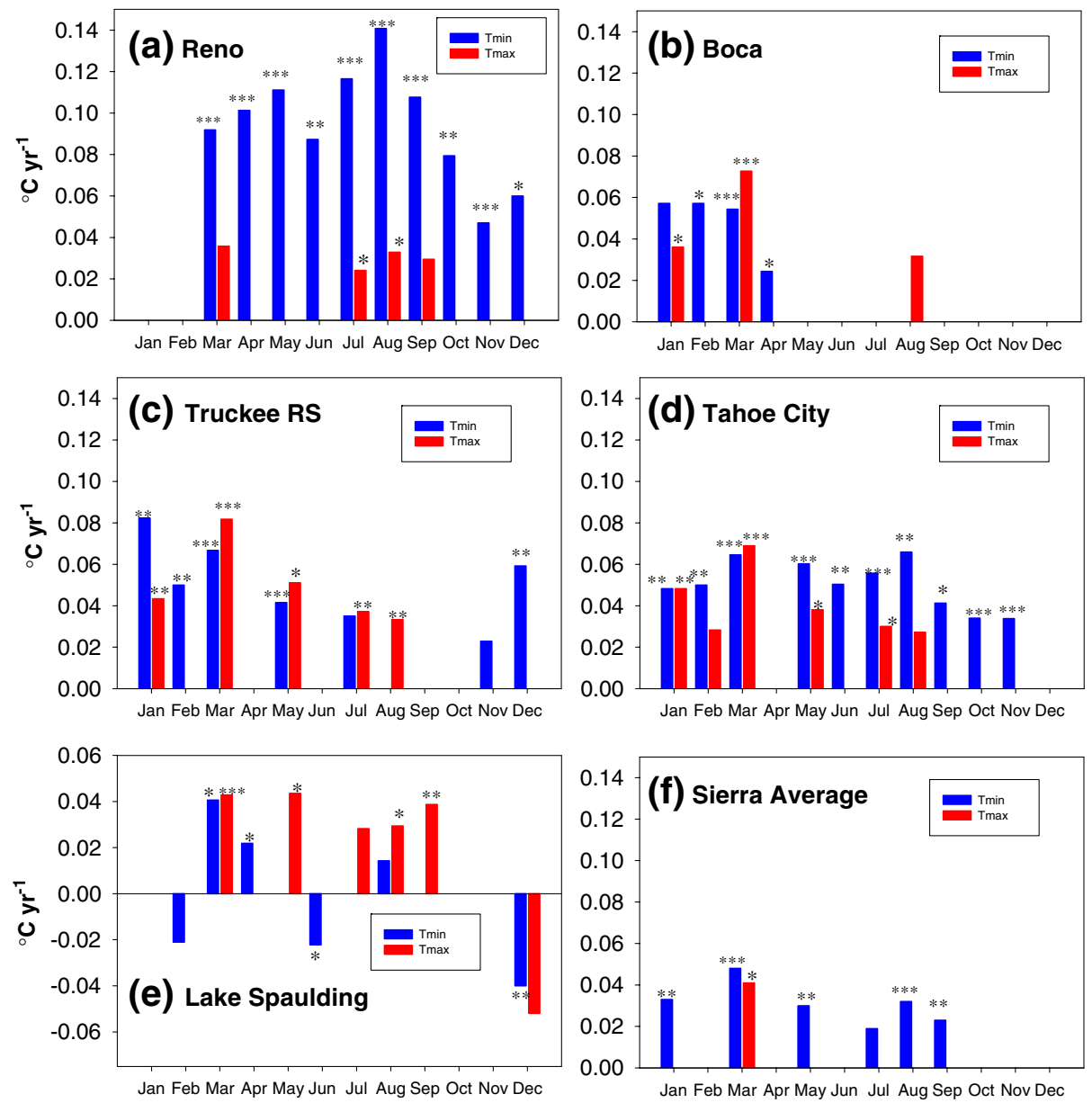

Fig. 3 Theil slope of trend in monthly averages of $T_{\max }$ and $T_{\min }$ at five stations in the Tahoe region, 1956-2005. Reno, Tahoe City and Lake Spaulding are part of the Historical Climatology Network $(\mathrm{HCN})$. Sierra average $(f)$ is from data of the Western Regional Climate Center. *** $P<0.01 ; * * P=$ $0.01-0.05 ; * P=0.05-0.10$; no asterisk $P=0.15-0.1$. No results are shown for months where $P>0.15$

Not only are the extremes in annual precipitation increasing, but the frequency of intense rainfall is also increasing. Figure 5 shows the time trend in the number of days per semi-decade that the 95th percentile value for daily rainfall amount$3.9 \mathrm{~cm}$-was exceeded. For comparison, the annual maximum daily 2-year rainfall amount is $6.3 \mathrm{~cm}$, based on a log-Pearson type III analysis, and $3.9 \mathrm{~cm}$ was equaled or exceeded (as an annual maximum) in 75 of the 98 years of record examined. Of the 221 events exceeding the 95th percentile daily amount, 91\% occurred in the months Nov. through May, when there is likely to be snow on the ground. This suggests a possible increase in rain-on-snow flooding. Mean annual rainfall by semi-decade explains $87 \%$ of the variance in number of events $>3.9 \mathrm{~cm}$ per semi-decade.

The Kendall test for trend in the number of exceedances per half-decade showed a tau correlation coefficient of 0.34 , with $P<0.045$. The rate of increase in frequency 
Table 4 Partition of Sums of Squares for Trend Homogeneity test (van Belle and Hughes 1984)

\begin{tabular}{lrrl}
\hline Source & $\chi^{2}$ & $d f$ & $P<$ \\
\hline Monthly average of $T_{\max }$ & & & \\
Total & 120 & 60 & $10^{-5}$ \\
Homogeneity & 58 & 59 & - \\
$\quad$ Monthly & 37 & 11 & $10^{-4}$ \\
$\quad$ Site & 6 & 4 & $\mathrm{~ns}$ \\
$\quad$ Site $\times$ month & 14 & 44 & $\mathrm{~ns}$ \\
Trend & 62 & 1 & - \\
Monthly average of $T_{\min }$ & & & \\
Total & 505 & 60 & $10^{-6}$ \\
Homogeneity & 233 & 59 & - \\
$\quad$ Monthly & 49 & 11 & $10^{-6}$ \\
$\quad$ Site & 136 & 4 & $10^{-6}$ \\
$\quad$ Site $\times$ month & 47 & 44 & $\mathrm{~ns}$ \\
Trend & 272 & 1 & - \\
\hline
\end{tabular}

of daily rainfall exceeding $3.9 \mathrm{~cm}$ is about one event per decade. This increase may be related to increases in the strength of ENSO events. The average January-June MEI shows a highly significant $\left(P<0.001, R^{2}=0.12\right)$ upward trend between 1950 and 2005. The years 1983, 1995 and 1997 were especially strong Niño years, and this is reflected in the data.

The striking thing about Fig. 5 is not just the upward trend in exceedance frequency for the 95th percentile daily amount, but also the apparent increase, beginning in 1975, of large positive and negative deviations from the upward trend. The increasing interannual variability in heavy rainfall events is consistent with the increasing variance in total annual rainfall.

The timing of snowmelt in the western USA is of major concern because of its implications for water supply. In the Tahoe basin, a shift in snowmelt timing may have implications for lake clarity and water quality. The analysis of SMPT in the

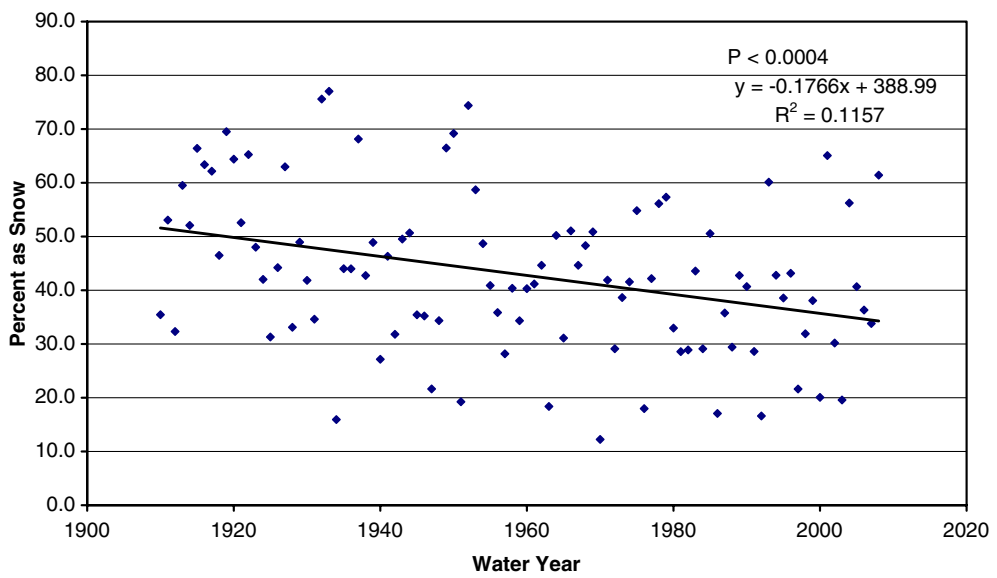

Fig. 4 Percent of total annual precipitation as snow at Tahoe City 




Fig. 5 Number of days per semi-decade that daily rainfall at Tahoe City exceeded $3.9 \mathrm{~cm}$, the 95th percentile value for days with rain

Tahoe basin shows a significant shift toward earlier dates in four of the five streams. Table 5 shows the results of the Kendall tests on the trend in SMPT after removal of the "total snowfall effect" for each water year and stream with the LOWESS smoothing. For the five Tahoe basin streams, the average shift toward earlier dates of the snowmelt peak is about 0.4 days year ${ }^{-1}$, with Theil slopes ranging from -0.205

Table 5 Results of the Kendall trend test on snowmelt peak timing (SMPT) ${ }^{\mathrm{a}}$

\begin{tabular}{llrlrrrr}
\hline Stream & $\begin{array}{l}\text { USGS } \\
\text { Sta. No. }\end{array}$ & \multicolumn{1}{c}{$\begin{array}{c}\text { Area } \\
\left(\mathrm{km}^{2}\right)\end{array}$} & $\begin{array}{l}\text { Period } \\
\text { used }\end{array}$ & $n$ & $\begin{array}{l}\text { Theil } \\
\text { Slope }\end{array}$ & $\begin{array}{l}\text { Tau Corr. } \\
\text { Coef. }\end{array}$ & $P<$ \\
\hline Tahoe basin streams & & & & & & & \\
$\quad$ Ward Creek & 10336676 & 25.2 & $1973-2005$ & 33 & -0.419 & -0.220 & 0.075 \\
Blackwood Cr. & 10336660 & 28.7 & $1971-2005$ & 35 & -0.205 & -0.137 & 0.187 \\
$\quad$ Upper Truckee & 10336610 & 139.9 & $1972-2005$ & 31 & -0.421 & -0.273 & 0.032 \\
Trout Creek & 10336780 & 95.1 & $1961-2005$ & 45 & -0.465 & -0.333 & 0.001 \\
Third Creek & 10336698 & 15.6 & $1972-2005$ & 33 & -0.453 & -0.223 & 0.070 \\
Average & - & & - & - & -0.393 & -0.149 & - \\
Non-Tahoe basin streams & & & & & & \\
Sagehen Creek & 10343500 & 27.2 & $1961-2005$ & 45 & 0.086 & 0.063 & 0.550 \\
S. Fk Yuba R. & 11414000 & 134.2 & $1949-1994$ & 46 & -0.116 & -0.067 & 0.520 \\
E. Fk Carson R. & 10308200 & 714.8 & $1961-2004$ & 44 & -0.089 & -0.066 & 0.537 \\
W. Fk. Carson R. & 10310000 & 169.4 & $1960-2004$ & 45 & 0.144 & 0.079 & 0.451 \\
\hline
\end{tabular}

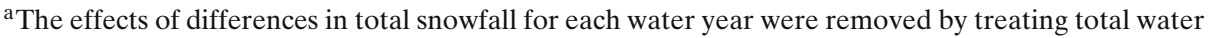
year snowfall as an ancillary variable, and testing the time trends of the LOWESS residuals (Helsel et al. 2005). For Sagehen Creek, snowfall at Truckee was used, for the S. Fk. Yuba, snowfall at Lake Spaulding, and for the forks of the Carson River, snowfall at the Coop Station at Twin Lakes (49105) was used. 
to -0.465 for the five creeks. Figure 6 shows the gaging station locations, trend slopes and significance level for both the in-basin and out-of-basin streams.

Figure 7 shows the trend in the average SMPT, for the five Tahoe basin streams. In this plot, the total snowfall effect was removed by OLS regression of SMPT vs. total water-year snowfall, and the residuals have been converted to date. This trend line has a slightly lower slope than the Theil slope from the Kendall test. Serial correlation is negligible $(r=0.08)$. On average, the timing of the spring snowmelt peak discharge (1961-2005) has shifted toward earlier dates at a rate of about 0.4 days year ${ }^{-1}$.


Fig. 6 Trend slopes, significance level and locations of gaging stations used in analysis of the shift in snowmelt timing 


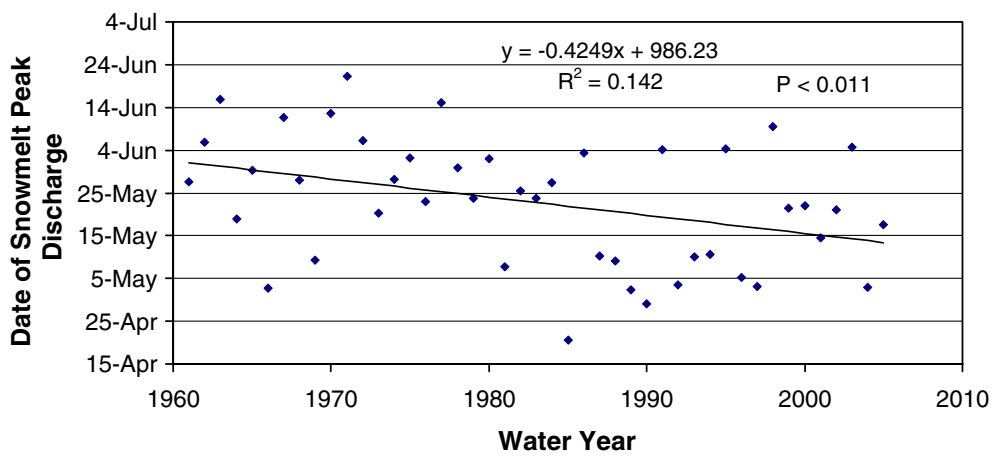

Fig. 7 Average date of snowmelt peak discharge for five streams in the Tahoe Basin, after removal of total annual snowfall effect

The SMPT for the four out-of-basin streams, however, showed no significant time trends. And surprisingly, the centroid timing (CT) for only one of the nine streamsthe South Fork Yuba, for the period 1943 to1994 - showed a significant trend, with a tau correlation coefficient of -0.20 , a slope of -0.32 days year ${ }^{-1}$, and $P<0.034$.

\subsection{Changes in lake temperature and thermal structure}

Since the average temperature of Lake Tahoe was last calculated through 2002 (Coats et al. 2006), the lake's annual minimum temperature has continued to increase, reaching its highest level ever in late February-early March, 2007. The annual maximum temperature, however, has not increased over the same period. Figure 8 shows the annual maximum, minimum and average of the daily volume-averaged lake temperature. Although the data used run through October 2007, they capture both the 2007 minimum lake temperature (in early spring) and annual maximum (in fall).

Figure 9 shows the temperature measured monthly at $400 \pm 20 \mathrm{~m}$ depth. The sharp drop in spring of 2007 resulted from deep mixing, probably to the lake bottom. This mixing event was unusual in that it occurred during a warm and early spring.

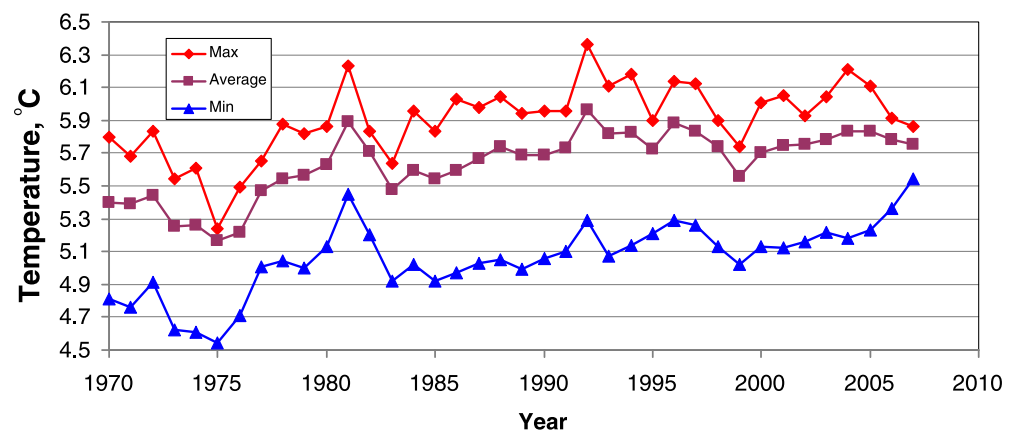

Fig. 8 Annual maximum, average, and minimum of volume-averaged daily water temperature of Lake Tahoe, 1970-2006 
Fig. 9 Temperature at $400 \mathrm{~m}$ in Lake Tahoe

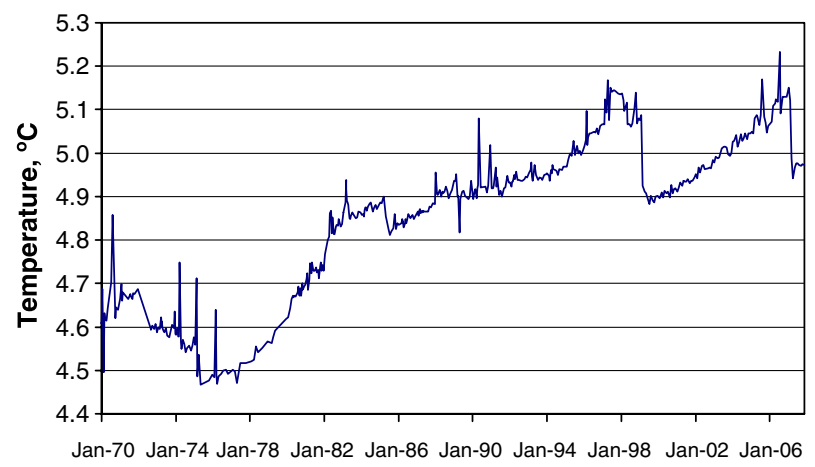

The spring and summer of 2006, however, were unusually cool, and the lake never warmed enough to create the usual degree of stratification. Apparently the slight cooling in late winter of 2007 was then sufficient to trigger a deep mixing event.

Figure 10 shows the deseasonalized average daily lake temperature. The low point in 2006 (relative to seasonal norm) was reached on September 18, as a result of the unusually cool summer. The large drop in, 1982-1983, is thought to be a result of the eruption of El Chichón in Mexico, March 1982.

The Seasonal Kendall Test for trend in the monthly average lake temperature found a tau correlation coefficient of 0.54 , a Theil slope of $0.013^{\circ} \mathrm{C} \mathrm{year}^{-1}$, and $P<$ $5 \times 10^{-5}$.

\subsection{The role of the Pacific decadal oscillation and El Niño/southern oscillation}

Table 6 summarizes the results of regression tests of the climatic and hydrologic variables against the PDO and MEI. Some of the climatic-driven variables are

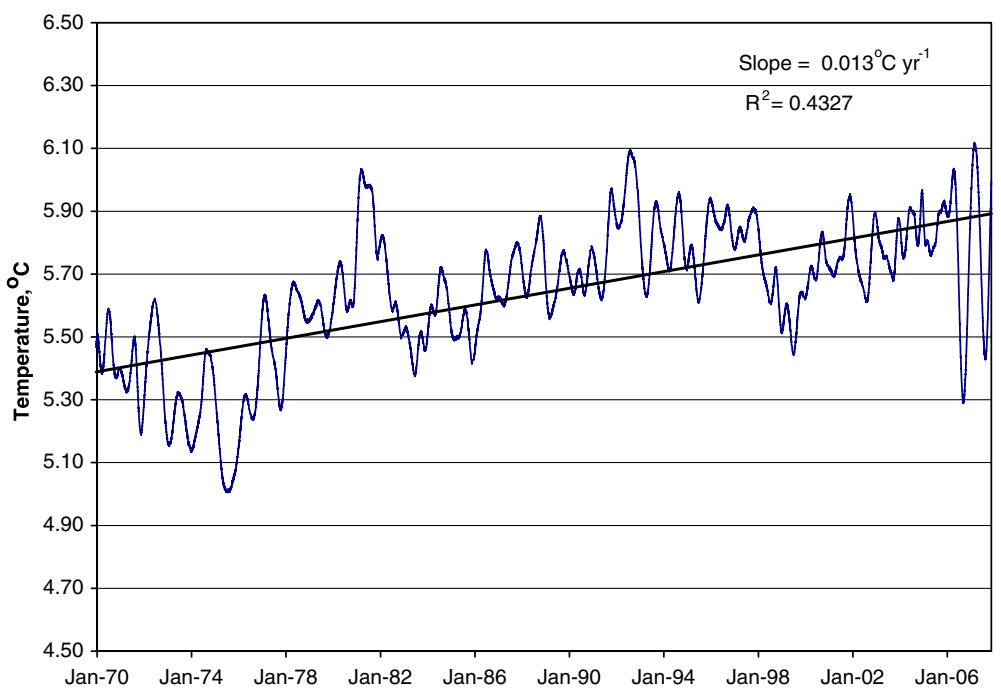

Fig. 10 Volume-averaged daily temperature of Lake Tahoe, de-seasonalized 
Table 6 Results of regression of air temperature, snowfall percent, day of snowmelt peak (SMPT) and lake temperature with indices of the Pacific decadal oscillation and El Niño/southern oscillation

\begin{tabular}{|c|c|c|c|c|c|}
\hline \multirow{2}{*}{\multicolumn{2}{|c|}{ Dependent variable }} & \multicolumn{2}{|l|}{ PDO } & \multicolumn{2}{|c|}{ MEI } \\
\hline & & $\overline{R^{2}}$ & $P<$ & $\overline{R^{2}}$ & $P<$ \\
\hline \multicolumn{2}{|c|}{ Monthly ave. of deseasonalized $T_{\max }$} & 0.019 & $10^{-5}$ & - & NS \\
\hline \multicolumn{2}{|c|}{ Monthly ave. of deseasonalized $T_{\min }$} & 0.035 & $10^{-9}$ & 0.03 & $1.5 \times 10^{-6}$ \\
\hline \multicolumn{2}{|c|}{ Ave. April-June deseasonalized $T_{\max }$} & 0.08 & 0.0076 & - & NS \\
\hline \multicolumn{2}{|c|}{ Ave. April-June deseasonalized $T_{\min }$} & 0.07 & 0.013 & 0.12 & $2 \times 10^{-6}$ \\
\hline \multicolumn{2}{|c|}{ Percent of annual WY precip. as snow } & - & NS & - & NS \\
\hline \multicolumn{2}{|c|}{$\begin{array}{l}\text { Day of peak snowmelt discharge, after } \\
\text { removal of tot. ann. snowfall effect } \\
\text { (with spring PDO and MEI) }\end{array}$} & 0.18 & 0.0004 & 0.06 & 0.11 \\
\hline \multicolumn{2}{|c|}{$\begin{array}{l}\text { Monthly ave. of deseasonalized daily } \\
\text { lake temp, lagged } 1 \text { month }\end{array}$} & 0.12 & $5 \times 10^{-14}$ & 0.1 & $6 \times 10^{-12}$ \\
\hline \multirow{4}{*}{$\begin{array}{l}\text { Seasonal ave. of } \\
\text { deseasonalized daily } \\
\text { lake temp, lagged } \\
1 \text { month }\end{array}$} & Spring & 0.17 & $4 \times 10^{-6}$ & 0.07 & $5 \times 10^{-3}$ \\
\hline & Summer & 0.21 & $2.5 \times 10^{-7}$ & 0.13 & $8 \times 10^{-5}$ \\
\hline & Fall & 0.05 & 0.008 & 0.10 & $7 \times 10^{-4}$ \\
\hline & Winter & 0.08 & 0.001 & 0.11 & $4 \times 10^{-4}$ \\
\hline
\end{tabular}

statistically related to both the PDO and the MEI. For deseasonalized monthly average of $T_{\max }$ and $T_{\min }$ at Tahoe City (1909-2005), the PDO explained only $1.9 \%$ and $3.5 \%$ of the variance, although the effects were highly significant $\left(P<10^{-5}\right.$ and $10^{-9}$, respectively). $T_{\min }$ but not $T_{\max }$ is related to the MEI, for monthly averages. For spring air temperature ( $T_{\max }$ and $T_{\min }$ ), the PDO connection is significant, but only the spring $T_{\min }$ temperatures are related to the MEI. There was no apparent effect of the average winter PDO or MEI on the percent of precipitation falling as snow (1909-2005), but there was a highly significant $(P<0.0004)$ relationship between the average spring (April-June) PDO and the SMPT. This relationship is shown in Fig. 11. When the residuals from the OLS regression are then regressed against date, there is no significant time trend $(P<0.24)$. The regression of SMPT versus average spring MEI was not quite significant $(P<0.11)$.



Fig. 11 Annual snowmelt peak Julian day vs. average April-June PDO. Snowmelt peak is average of 5 streams in the Tahoe Basin, after removal of total annual snowfall effect 


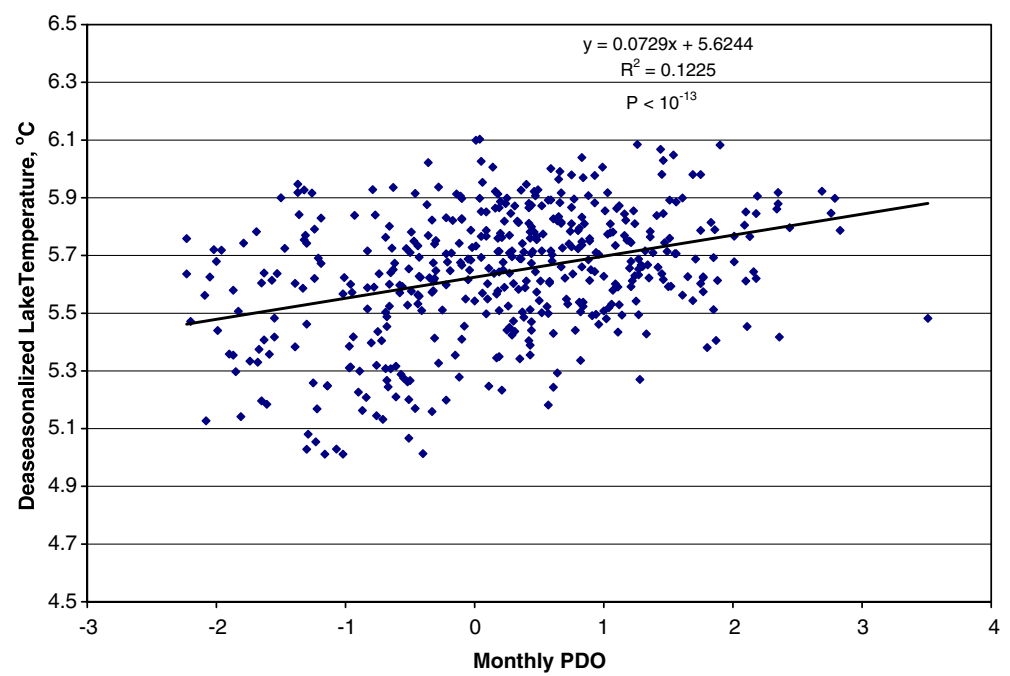

Fig. 12 Monthly average of deseasonalized lake temperature vs. PDO in previous month, 1970-2007

The warming trend in the lake also seems to be linked to both the PDO and ENSO, with each explaining about $10 \%$ of the variance in monthly average of deseasonalized average daily lake temperature. Figure 12 shows relationship for the PDO. When the residuals from this regression are heavily pruned to eliminate the effect of serial correlation, the Kendall test shows that remaining time trend is still highly significant, with $P<0.006$. The Theil slope of the remaining trend is $0.0156^{\circ} \mathrm{C} \mathrm{year}^{-1}$, which is close to the slope of the original deseasonalized data. The lake temperatures seem to be a little more closely related to the spring and summer PDO than to the fall and winter PDO, but the relationship between lake temperature and the MEI does not vary with season (see Table 6). Lagging the lake temperature 1-2 months behind the PDO makes only a slight difference in the regression results.

\section{Discussion}

\subsection{Air temperature trends}

The warming trends shown here-both annual (for the useable period of record at each station) and monthly (1956-2005) - are generally consistent with much of the research on warming trends in the western USA. In a study on declining snowpack in western North America, Mote et al. (2005) found "overwhelmingly positive" trends in mean November-March temperatures for the periods 1930-1997 and 1950-1997, with the highest warming rates in the more recent period. Bonfils et al. (2008b) found seasonal increases in temperature in California as high as $2.0^{\circ} \mathrm{C}$ during the 1950 1999 period, with faster warming in late winter and spring, and less rapid warming in summer and fall. Warming rates are generally higher at night $\left(T_{\min }\right)$ than in daytime $\left(T_{\max }\right)$. 
The warming rate in California varies considerably by region, however, with the highest rates in northwest, south coast, and southeast desert climatic divisions, a lower rate in the central valley and central coast, and a slight cooling trend in the NE interior basins. LaDochy et al. (2007) suggest that some of these differences may be due to urbanization, and question the notion of uniform climatic controls over the climatic divisions. My study area falls near and over the western edge of the NE interior basins division.

At some of our stations and in some months, the results are surprising. The extraordinary warming trend at Reno in $T_{\min }$, especially in the summertime (up to $0.14^{\circ} \mathrm{C}$ year $^{-1}$ ) may be due the rapid growth in landscape and agricultural irrigation. The desert valley around Reno has been developed rapidly since the mid-1950s, using both surface water from the Truckee River, and groundwater supplies. Christy et al. (2006) found that the night-time temperatures in the San Joaquin Valley of California are increasing faster than in the foothills and Sierras. They attributed the difference primarily to the darkening and moistening of the soil surface, which decreases albedo and increases heat storage capacity, and secondarily to increased night-time humidity. Note that the monthly averages of $T_{\max }$ at Reno in this study showed significant increases $(P<0.10)$ only in the months of July and August, possibly due (as suggested by Bonfils et al. 2008b) to a cooling effect of irrigation on daytime temperatures.

In a study of regional temperature trends in agricultural areas of California, Lobell and Bonfils (2008) found by regression analysis that irrigation caused substantial cooling in $T_{\max }$, but $T_{\min }$ trends were more positive for non-irrigated than for irrigated sites. Spatial analysis indicated that the upward trends in $T_{\min }$ previously attributed to irrigation could best be attributed to urbanization. It must be noted, however, that urbanization in the arid valleys of California and Nevada generally includes significant increases in landscape irrigation.

The Reno temperature record is part of the Historical Climatology Network, and the data have been adjusted for urbanization on the basis of population growth. The data used in the adjustment, however, were drawn almost entirely from temperature records in the central and eastern USA, with very few stations in the arid West. (Karl et al. 1988). Kalnay and Cai (2003) found that the mean surface warming rate due to land use changes in the USA is at least twice as high as previous estimates based on urbanization alone. The Reno data suggest that if the goal is to determine air temperature trends on a regional or global scale, then some additional adjustment may be necessary in arid regions where land use change has been rapid.

The warming trends at Boca, Truckee and Tahoe City present an interesting contrast. At Boca and Truckee, the warming trends in $T_{\max }$ and $T_{\min }$ are highest during winter and spring, and decrease to a minimum in the fall. This is consistent with the results of Abatzoglou and Redmond (2007), who found that trends in spring circulation patterns over the western USA tend to enhance regional warming, whereas autumn circulation patterns counteract it.

At Tahoe City, however, warming rates (especially in $T_{\min }$ ) are high through the summer, and decrease only slightly in the fall. The Tahoe City $T_{\min }$ trend slopes are second only to the slopes at Reno. Since the relatively minor effect of urbanization at Tahoe City has been removed in the HCN monthly average data, and there is no agricultural and little landscape irrigation, we must look for another explanation for locally-enhanced warming. Two hypotheses are presented below, in Section 4.2. 
The temperature trends at Lake Spaulding present a slightly different pattern from other stations, with higher $T_{\max }$ than $T_{\min }$ warming rates in late summer, and significant cooling in both $T_{\max }$ and $T_{\min }$ in December. The station is on west side of the Pacific Crest, and may be more influenced by climate trends in the Sacramento Valley.

\subsection{Precipitation and snowmelt}

Declining snowpacks in the western USA have been the source of a number of recent studies, using both empirical analysis of data and climate modeling (Mote et al. 2005; Barnett et al. 2008; Dettinger and Cayan 1995; Hamlet et al. 2005; Stewart et al. 2004). The results of these studies have raised considerable alarm among water managers, since much of the water supply in the west is dependent on a snowpack that persists into late spring or early summer. In California, the projected severe reduction in the summer snowpack will mean the loss of the largest storage reservoir in the state. At Lake Tahoe as elsewhere in the Sierra Nevada, the declining snowpack on April 1 results from both a shift from snow to rain, and a shift in the timing of snowmelt toward earlier dates.

Knowles et al. (2006) measured the percent of annual precipitation falling as snow for 207 stations in the western USA, for the period 1949-2004. They found that for stations with a significant time trend (tested by the Kendall test) $84 \%$ showed a decline in the fraction of precipitation falling as snow. The strongest declines were at lower elevation sites in the Sierra Nevada and the Pacific Northwest. The average rate of decline in snow water equivalent (SWE) for all stations as percent of total precipitation was $0.16 \%$ year $^{-1}$, slightly less than the rate of $0.19 \%$ year- ${ }^{1}$ found in this study for Tahoe City, during the period 1910-2005.

The sensitivity of the snowpack to the effects of climate warming (for a given latitude) is strongly related to elevation. A climate modeling study by Knowles and Cayan (2004) found that in the northern Sierra, $85 \%$ of the losses in the April snow water equivalent (SWE) by 2060 will occur in between elevations 1300 and $2200 \mathrm{~m}$. About 53.4\% of the Tahoe basin lies between 1900 and $2200 \mathrm{~m}$ elevation. For the northern Sierra, Knowles and Cayan projected a reduction in the April SWE volume of about $38 \%$ by 2060 . Johnson et al. (1999) found (on the basis of snow survey data for the Sierra Nevada) trends toward less snow accumulation and earlier melt at elevations below $2400 \mathrm{~m}$, and trends toward higher accumulation and earlier melt at higher elevations.

A number of methods and data sets have been used to measure the trends in snowmelt timing in the western USA. The metrics used have included the monthly and/or fractional seasonal flows (Roos 1991; Stewart et al. 2005), the date of the beginning of spring snowmelt runoff pulse (Cayan et al. 2001; Stewart et al. 2005), and date of the annual hydrograph centroid (CT; Stewart et al. 2005; Barnett et al. 2008). Table 7 summarizes the trends that the various studies have found for the different metrics and time periods used. The shift in snowmelt timing in the Tahoe basin of 0.4 days year ${ }^{-1}$ as measured by the date of snowmelt peak runoff (SMPT) in this study is on the high side compared with the published results for other areas around the west. Stewart et al. (2005) found an average shift toward earlier dates for CT of 0.13 days year ${ }^{-1}$ for the western USA. For $73 \%$ of their snow-dominated stream 


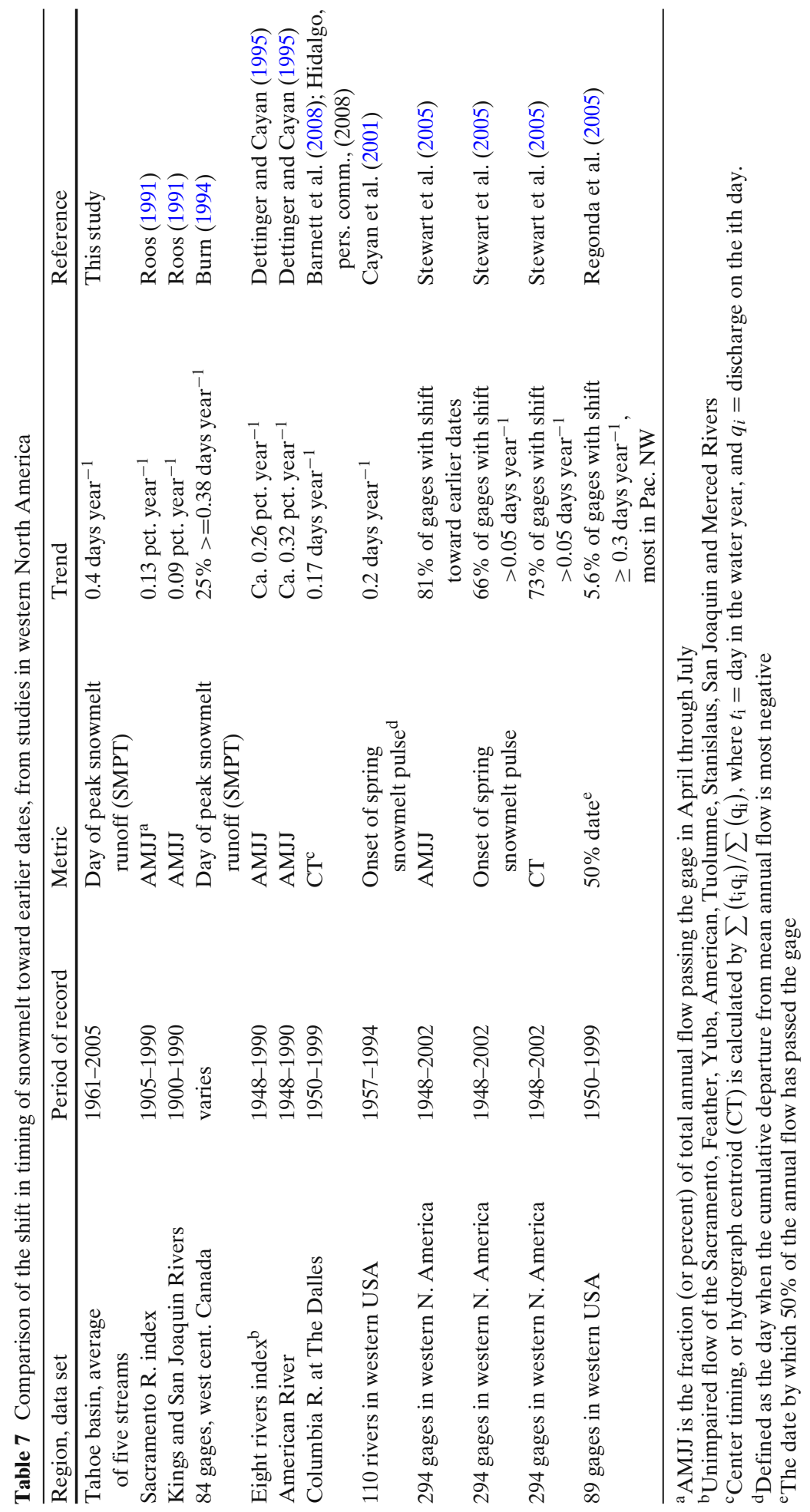


gages around the West, the shift toward earlier CT dates was at least 0.05 days year ${ }^{-1}$. Only $5 \%$ of their gages showed a shift of 0.40 days year ${ }^{-1}$ or more, and none of these were in California (Stewart-Frey, pers. comm. 2008). In Burn's (1994) data set, only $25 \%$ of the gages showed a shift in SMPT $\geq 0.38$ days year ${ }^{-1}$.

It is instructive to compare the snowmelt timing shift for in-basin and out-of-basin streams, for the two metrics used here. The time trend for in-basin streams by the SMPT method is clear, while the out-of-basin streams show no such trend. However, the drainages of the East and West Forks of the Carson river cover a larger elevation range than the in-basin streams, so the apparent spring runoff peaks there could be affected by rain in the lower basin. In a study based on 30 years of snow survey data (1966-1996) from 260 snow courses in the Sierra Nevada, Johnson et al. (1999) found that the Tahoe basin had the highest loss-54\% - in May SWE of any of the 21 river basins studied.

It may seem paradoxical that only one of the nine streams-the South Fork Yuba-showed a significant trend in CT. But timing of CT and the SMPT respond to different factors in the annual runoff cycle. Figure 13 shows the annual hydrographs for two contrasting water years at Blackwood Creek. In 1982, large winter rainstorms resulted in an early CT date, 56 days ahead of the SMPT. In 2002 (a relatively dry year), there were no major winter rainstorms, but there was a rapid onset of spring thaw, so the SMPT actually preceded the CT date by 15 days. The CT date thus reflects the entire water year (including fall and winter rainstorms), whereas the SMPT (with the snowfall effect removed) responds primarily to spring air temperatures. Since spring air temperatures in the northern Sierra are increasing faster than fall air temperatures, it is reasonable to expect to find time trends in the SMPT for some streams where there is no trend in CT.

Both the air temperature and snowmelt timing results suggest that the Tahoe basin is warming faster than the surrounding region. Two hypotheses (not mutually exclusive) are suggested to explain why. The first is the "lake climate change enhancement hypothesis". Rouse et al. (2005), working in northern Canada, showed how large lakes (such as Great Slave Lake) can influence a regional energy budget. With a low albedo and high heat storage capacity relative to the land surface, much of the shortwave energy striking the lake surface is stored (25-75\% for Great Slave Lake) and released later as latent and sensible heat, and long-wave (LW) radiation. The outgoing LW energy from the lake (and overlying atmospheric boundary layer) is thus greater than it would be absent the lake. The MODIS satellite images of Tahoe in Fig. 14, from July and August 2007, show the contrast between the lake and surrounding land for daytime reflected radiation, and nighttime emitted longwave radiation. Greenhouse gases (GHGs) should intercept the same fraction of outgoing LW radiation from the lake surface as from the land surface, and over time, as GHGs increase, the fraction intercepted should increase. If the LW radiation emission rate of the lake exceeds that of the land, then in absolute terms, the atmospheric energy absorption (and the air temperature) over the lake should increase faster than over the land. This hypothesis could best be tested with a regional climate model coupled to the existing Lake Tahoe temperature model, and embedded in a GCM (Cohen 1990).

The second hypothesis is the "snow albedo perturbation hypothesis". Qian et al. (2009) modeled soot deposition and its effects on snow albedo, climate and hydrology in the western USA, using chemistry and regional climate configurations of the weather research and forecasting model (WRF) and NOAA land surface model 
Fig. 13 Hydrographs for two contrasting water years, Blackwood Creek, showing the relationship between hydrograph centroid (CT) and snowmelt peak timing (SMPT). Vertical lines indicate the CT date
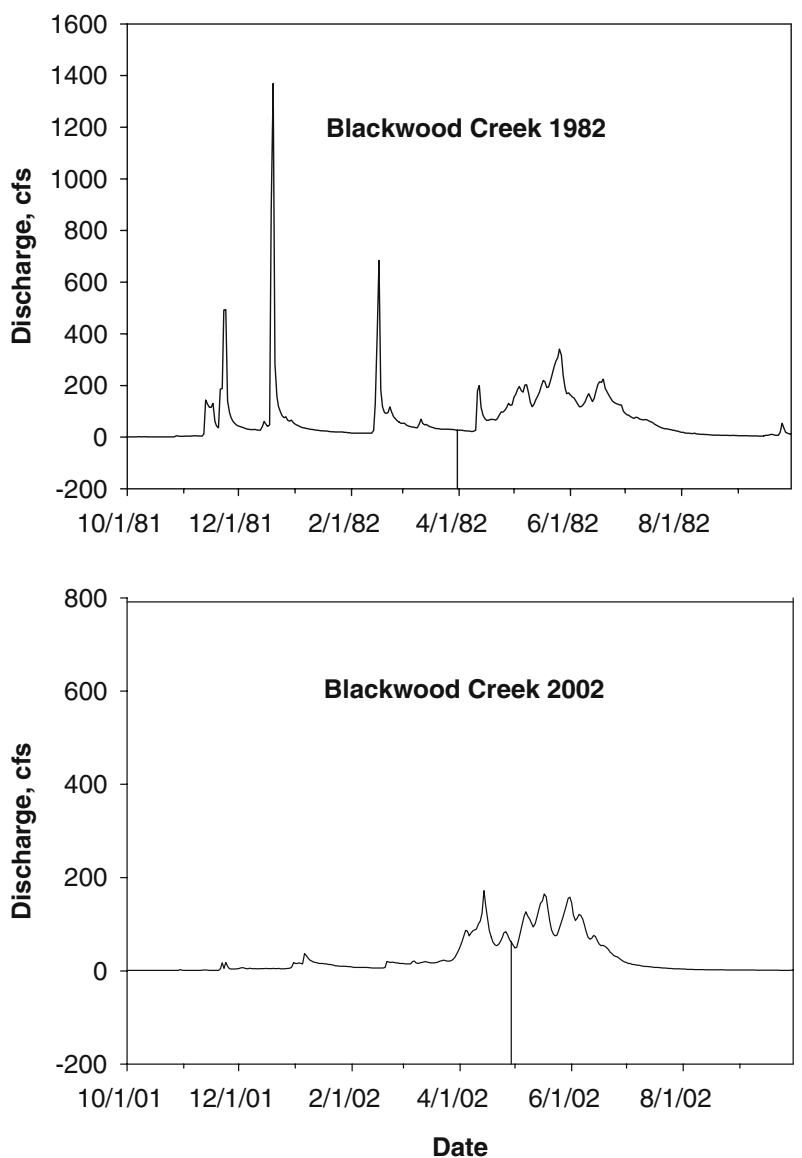

a

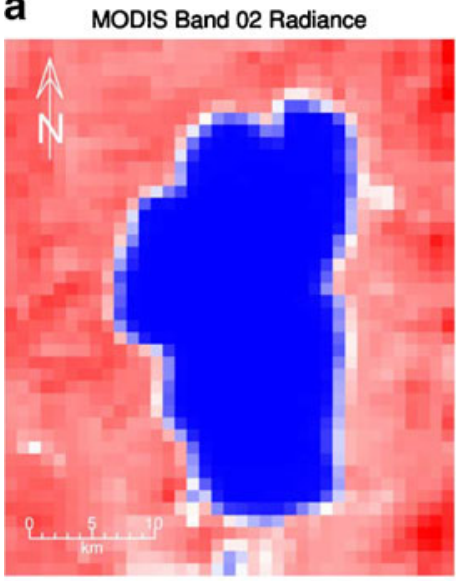

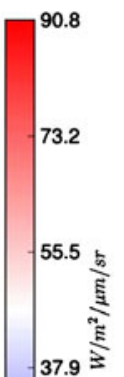

b MODIS Band 31 Radiance

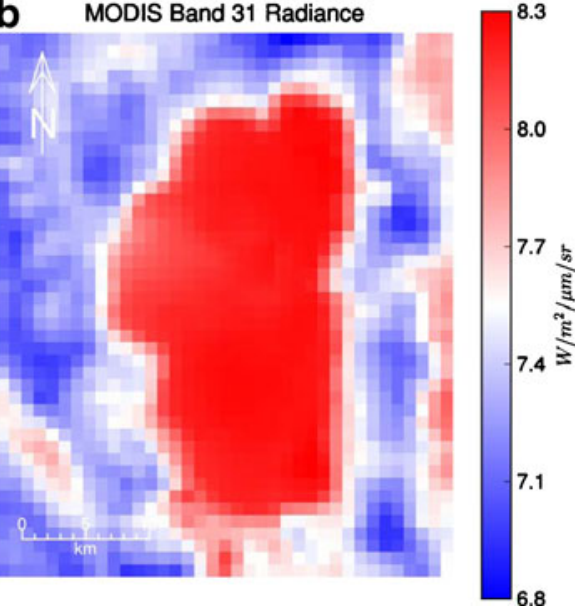

Fig. 14 MODIS satellite images of Lake Tahoe, day and night, at mid-summer. a Reflected Near-IR radiation, 0.84-0.85 $\mu \mathrm{m}$, at 10:50 AM PST, 7/31/2007. b Outward Long wave radiation, 10.8-11.3 $\mu \mathrm{m}$, at 10:10 PM PST, 8/5/2007. Source: Todd Steissberg, Univ. California at Davis 
(LSM). They found that soot-induced albedo perturbation (at realistic emissions levels) not only causes a shift in snowmelt timing toward earlier dates, but also (as a result of several positive feedback mechanisms) causes higher air temperatures and a shift from snowfall to rain-trends that seem to be occurring more intensely in the Tahoe Basin than the surrounding region. For the Sierra Nevada, their modeling results showed that the reduction in snow water equivalent (SWE) was greatest in April, amounting to $1.4 \mathrm{~mm}$, or $-1.6 \%$. February runoff in the Sierra Nevada increased by $1.0 \%$, and May runoff decreased by $0.6 \%$. The spatial scale of the model used, however, cannot account for emission "hot spots" or the steep climatic gradients that are typical in mountainous terrain (Dobrowski et al. 2009)

The Tahoe basin has abundant winter-time emission sources of soot, most of which is black carbon. Many homes are heated with wood-burning stoves, and traffic during the ski season is heavy at times. Although there are no data on the black carbon (BC) content of snow in the basin, air quality data are available for a station at South Lake Tahoe (SLT), and at Bliss State Park (BSP), on the west shore (IMPROVE 2009). Figure 15 shows the time trends in annual water-year average of near-surface concentration of Fine Total Elemental Carbon $(<2.5 \mu \mathrm{m}$, December, January and February), compared with values at Lassen Volcanic National Park (LVNP). SLT is the most urbanized area of the basin and had the highest Elemental Carbon concentrations, averaging $2.02 \mu \mathrm{g} \mathrm{m}^{-3}$. BSP is less influenced by local sources, but like the rest of the basin is down-wind from major metropolitan areas in Sacramento Valley and Bay Area. The average concentration was $0.16 \mu \mathrm{g} \mathrm{m}^{-3}$. LVNP $(220 \mathrm{~km}$ NNW of SLT) is more remote and less affected by in-state sources, and thus had lower BC concentrations than the Tahoe stations, averaging $0.076 \mu \mathrm{g} \mathrm{m}^{-3}$. The percentiles for concentrations at SLT, BSP and LCNP in the IMPROVE data base for the entire USA (DJF, $n=31,043$ ) were respectively 99.2, 52 and 27. The correlation between BSP and LVNP $\left(R^{2}=0.74, P<10^{-4}\right)$ suggests a remote background source, possibly in Asia (Tollefson 2009).

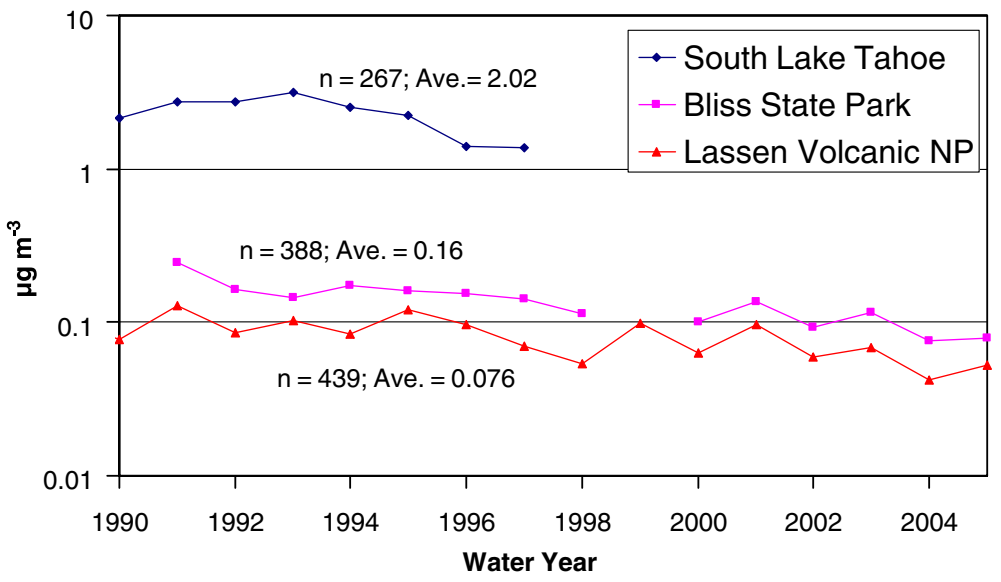

Fig. 15 Annual averages of near-surface atmospheric fine total elemental carbon concentration $(<2.5 \mu \mathrm{m})$, December, January and February, at South Lake Tahoe, Bliss State Park and Lassen Volcanic National Park 
Efforts to test the snow albedo perturbation hypothesis might include intensive snowpack energy budget studies, together with sampling and measurement of BC concentrations in the spring snowpack throughout the basin. The California Cooperative Snow Surveys (CCSS; see http://cdec.water.ca.gov/snow/) play an important role in the management of California's water resources. It would be appropriate for the CCSS to begin monitoring the black carbon concentration in the snowpack at selected snow survey courses in the Sierra Nevada.

The impacts of hydrologic changes on the lake will depend not just on timing of snowmelt and average runoff, but also on changes in the magnitude/frequency relationship of extreme events. The streamflow and precipitation records for the Tahoe basin are not long enough to permit an analysis of time trends in extreme events, but the daily precipitation record at Tahoe City provides a basis for comparing the historic trend in moderate rainfall amounts with modeled estimates of future changes. Kim (2005) modeled the changes that may occur in the relative magnitude of the 95 th percentile wet day precipitation (the amount exceeded by $5 \%$ of the days with rainfall $>0.5 \mathrm{~mm}$ ) in the northern Sierra in response to a one percent year ${ }^{-1}$ rate of increase in atmospheric $\mathrm{CO}_{2}$ from, 1990. His model results showed that by 2040-2049, the increase at an elevation of $1900 \mathrm{~m}$ will amount to 1.6 times as much rainfall, and 2.6 to 2.8 times as much discharge in large river basins, compared the control (stationary $\mathrm{CO}_{2}$ ). The measured increase in the frequency of rainfall events that equal or exceed Kim's 95th percentile criterion indicates that rainfall intensity in the basin is already increasing, at an average rate of about one event per decade. This is not a large change in frequency for events that are already relatively frequent, but may reflect a concomitant increase in larger, less frequent rainfall events. Such an increase, combined with the shift from snowfall to rainfall, will increase the frequency and magnitude of rain-on-snow events, which account for the largest floods in the Tahoe basin. Although we do not have data to measure changes in the frequency of rare and short-duration events, it seems likely that increases in rainfall intensity (alternating with periods of drought, with low soil moisture and poor plant growth) are accelerating channel and surface erosion, and the transport of fine sediment to the Lake (Cooke and Reeves 1976).

\subsection{Role of the PDO and ENSO}

There do seem to be connections between both the Pacific decadal oscillation and ENSO (as measured by the multivariate ENSO index, or MEI), and some the climatic variables examined for the Tahoe basin. For monthly air temperature, the relationship between PDO the monthly average temperature is slight, but statistically significant for both $T_{\max }$ and $T_{\min }$; for the MEI, it is significant only for $T_{\min }$. For average spring temperature, the relationship between air temperature and the PDO is stronger (Table 6). However, the residuals after removing the effect of the PDO by OLS regression from the average spring $T_{\min }$ still show a strong upward trend with time $\left(R^{2}=0.32 ; P<10^{-8}\right)$. This is important in interpreting the relationship between the shift in snowmelt timing and the PDO.

The shift in timing of peak snowmelt (SMPT) is linked to the PDO, with $R^{2}=0.20$ and $P<0.0022$. It is also linked to the MEI, but to a lesser degree, with $R^{2}=0.08$ and $P<0.06$. When the residuals of the SMPT versus PDO regression are regressed against year, there is no significant time trend. This cannot be interpreted to mean 
that the snowmelt timing shift is driven by the ocean temperature variables expressed in the PDO rather than by a long-term global warming trend, for two reasons. First, the hydrologic record used in the analysis of snowmelt timing spans the 1976-1977 step-change in the PDO from negative to positive values, which could exaggerate the importance of the PDO (Stewart et al. 2005). Second, the long-term $T_{\min }$ record shows a strong upward trend even after the PDO effect is removed. Since snow melts faster in a warm spring, the long-term trend in air temperature (independent of the PDO) must be an important factor in the shift in snowmelt timing.

As Fig. 12 and Table 6 show, the monthly average deseasonalized lake temperature is slightly related to the PDO, most strongly in spring and summer. But when the PDO effect is removed, and the data pruned to reduce serial correlation, the Kendall test shows that the upward time trend in the residuals is still significant $(P<0.006)$. As with the factors driving the shift in snowmelt timing, it seems that the long-term upward temperature trend in air temperature (presumably forced by GHG emissions) is the engine of change in the Tahoe basin, and the PDO and ENSO are part of the drive train.

4.4 Changes in Lake temperature and thermal structure: biological and water quality implications

Although there is clearly a long-term upward trend in the temperature of Lake Tahoe, the pattern of temperature change in since 2004 has been unusual in that the maximum annual temperature has declined while the minimum has increased (see Fig. 8). The recent decline in annual maximum is probably due in part to deep mixing that occurred in both 2007 and 2008 (Schladow 2009), when heat transported downward by eddy diffusion was released to the atmosphere. The continued upward trend in minimum temperature may be due to a series of mild winters.

The most significant effect of the warming trend in the lake is not its direct biological effect on organisms (though that may eventually become important) but rather its effect on the thermal stability of the lake. Coats et al. (2006) calculated the Schmidt Stability, Birge Work and Total Work, for the period, 1970-2002. These metrics relate to the work required to mix a thermally-stratified lake to an isothermal state, and the external energy required to produce a given degree of stratification. The upward trend in all three parameters was highly significant.

More recently, Winder et al. (2009) calculated annual and monthly average values of the Brunt-Väisälä frequency as an indicator of stratification strength. They found a significant increase in the intensity of stratification (1980-2006) in the 2-60 m depth interval $(P<0.008)$, and a tendency toward increased shoaling (decreasing depth) of the thermocline during stratification $(P<0.08)$. They were able to relate changes in phytoplankton populations to increasing stratification, finding that reduced vertical mixing is providing a competitive advantage to small-bodied diatoms and other algae that are relatively buoyant and have lower sinking velocities. The less-buoyant species tend to sink below the photic zone, and with reduced mixing, are unable to return.

Over a time scale of several decades, however, temperature changes may directly affect the growth and competitive advantage of organisms in the lake. In the late 1980s largemouth bass (Micropterus salmoides) and bluegill (Lepomis macrochirus) showed up in a shallow lagoon at the southern end of the lake, probably as a result of 
illegal introductions by anglers. They are now spreading into shallow lagoons around the margins of the lake, and are competing with and consuming native fish (Kamerath et al. 2008). Using the regional climate model (RegCM 2.5) of Snyder and Sloan (2005), together with an empirical model of lake surface temperature, Ngai (2008) showed that surface water temperatures in the lake may increase by as much as $3.0^{\circ} \mathrm{C}$ by 2080-2099 in the open lake, with larger increases in marinas and other shallow lagoons. She concluded that the warming trend will make the lagoons and ultimately the open lake more hospitable to the bass and bluegill. Increased populations of these fish could have important consequences for food web structure, nutrient recycling and lake water quality.

The changes in the lake's thermal structure may interact with changes in basin hydrology in ways that are difficult to predict. An important variable that influences the impact of sediment-rich stream discharge on water clarity is the "insertion depth". Streams entering the lake do so at the depth where the density of the stream water is equal to the density of the lake. The former is influenced by the timing of snowmelt and storm runoff, and by the suspended sediment concentration, and the latter by the seasonal cycle of warming, stratification and mixing. Additional modeling may help to sort out the interaction between stream runoff, lake thermal structure and water clarity, but it seems likely that increased inflow of fine sediment (from more intense rainfall, drought and wildfires) will interact with increasing thermal stability to prolong the period of reduced water clarity that follows periods of heavy runoff (Jassby et al. 1999).

An important question not yet resolved is: what will be the long-term effect of decreased mixing combined with on-going eutrophication on the concentration of dissolved oxygen (DO) at the bottom of the lake? If reduced mixing suppresses the downward flux of DO enough to cause anoxia at the sediment-water interface, the reduction of ferric to ferrous iron would trigger a release of phosphorus to the water column. The result could be a rapid state-change for the lake, from a ultraoligotrophic and blue, to mesotrophic and green. Additional modeling and careful measurement of DO profiles are needed to resolve this question.

\section{Summary and conclusions}

This study analyzed air temperature, precipitation, lake temperature and stream discharge data at daily to decadal time scale for sites in and around the Tahoe basin. The major findings are as follows:

1. Annual and monthly averages of air temperature records show upward trends, with the strongest trends for monthly $T_{\min }$ at Tahoe City and Reno. Monthly trends are generally strongest in spring, and weakest in the fall.

2. At some air temperature stations, anomalous trends may be explained by local microclimatic effects or changes in station location.

3. The air temperature and precipitation data for Tahoe City show a shift from snow to rain, a decline in the number of winter days below freezing, and an increase in the intensity of rainfall over the period 1910-2007.

4. Streamflow records in the Tahoe basin show a shift toward earlier dates in the peak of snowmelt runoff, for the period 1961-2005. A similar shift was not found for four streams outside of the Tahoe basin. 
5. The annual hydrograph centroid (CT) for nine stream gaging stations (both within and outside the Tahoe basin) showed a trend toward earlier dates only for the South Fork Yuba River, 1949-94.

6. Lake Tahoe warmed at an average rate of about $0.013^{\circ} \mathrm{C}$ year ${ }^{-1}$ during the period 1970-2007. The warming is increasing the lake's thermal stability and resistance to mixing, with important biological and biogeochemical implications and impacts.

7. The trends in air temperature, snowmelt timing and lake temperature (19702007) are statistically linked to the Pacific decadal oscillation, and to a lesser extent to El Niño-Southern Oscillation, but these large-scale climatic oscillations can explain only a small part of the variance in descriptors of Tahoe basin climate and hydrology.

8. The air temperature and streamflow records for stations in and around the Tahoe basin suggest that the lake itself may be enhancing the effect of GHGs on warming trends in the basin. This "lake enhancement" hypothesis is supported by work in Canada on the regional climatic effect of large lakes.

9. Atmospheric deposition of black carbon in the Tahoe basin may be implicated in the shift in snowmelt timing, increasing air temperature and the shift from snowfall to rain. Snowpack energy budget studies together with analysis of snowpack black carbon concentrations are needed to test this "snow albedo perturbation" hypothesis. Monitoring of black carbon in snow should be added to routine water quality monitoring in the Tahoe basin, and to the California Cooperative Snow Surveys.

10. Modeling studies that link the lake processes to basin hydrology and regional climate may be useful in understanding the likely long-term impacts of climate change on water quality and biota of Lake Tahoe, and how the lake's heat budget interacts with the basin's climate. A high resolution climate model for the Tahoe basin embedded in a GCM is needed to investigate the interactions between the lake and the regional climate.

11. In relocating coop stations, the National Weather Service needs to pay more attention to the microclimatic effects of large water bodies, topography and landscape irrigation.

Acknowledgements I thank John Reuter, Iris Stewart-Frey and Monika Winder, Gayle Dana and one anonymous reviewer for discussion, encouragement and/or thoughtful review of the manuscript; Scott Hackley, for help with installing and operating data loggers at Glenbrook; Norman Hansen and the crew at Station 5, for access to the old and current Glenbrook instrument locations, Todd Steissberg for providing the MODIS figures, Patricia Arneson for data stewardship, Janet Brewster for cartography, and Charles Goldman and Geoffrey Schladow for support and encouragement over many years. This research was supported in part by grant \#08-DG-11272170-101 from the USDA Forest Service Pacific Southwest Research Station using funds provided by the Bureau of Land Management through the sale of public lands as authorized by the Southern Nevada Public Land Management Act.

Open Access This article is distributed under the terms of the Creative Commons Attribution Noncommercial License which permits any noncommercial use, distribution, and reproduction in any medium, provided the original author(s) and source are credited. 


\section{References}

Abatzoglou JT, Redmond KT (2007) Asymmetry between trends in spring and autumn temperature and circulation regimes over western North America. Geophys Res Lett 34:1-5

Aguado E, Cayan D, Riddle L, Roos M (1992) Climatic fluctuations and the timing of west coast streamflow. J Clim 5:1468-1483

Arhonditsis GB, Brett MT, DeGasperi CL, Schindler DL (2004) Effects of climatic variability on the thermal properties of Lake Washington. Limnol Oceanogr 49:256-270

Barnett TP, Pierce DW, Hidalgo HG, Bonfils C, Santer BD, Das T, Gala G, Wood AW, Nozawa T, Mirin AA, Cayan DR, Dettinger MD (2008) Human-induced changes in the hydrology of the Western United States. Sci Express 319:1080-1083

Bonfils C, Santer BD, Pierce DW, Hidalgo HG, Bala G, Das T, Barnett TP, Cayan DR, Doutriaux C, Wood AW, Mirin A, Nozawa T (2008a) Detection and attribution of temperature changes in the mountainous western United States. J Clim 21:6404-6424

Bonfils C, Duffy P, Santer B, Wigley T, Lobell D, Phillips T, Doutriaux C (2008b) Identification of external influences on temperatures in California. Clim Change 87:S43-S55

Brown TJ, Hall BL, Westerling AL (2004) The impact of twenty-first century climate change on wildland fire danger in the western United States: an applications perspective. Clim Change 62:365-388

Burn DH (1994) Hydrologic effects of climate change in west-central Canada. J Hydrol 160:53-70

Cayan DR, Kammerdiener S, Dettinger M, Caprio J, Peterson D (2001) Changes in the onset of spring in Western United States. Bull Am Meteorol Soc 82:319-415

Christy J, Norris W, Redmond KT, Gallo K (2006) Methodology and results of calculating Central California surface temperature trends: Evidence of human-induced climate change? J Clim 19:548-563

Coats RN, Perez-Losada J, Schladow G, Richards R, Goldman CR (2006) The warming of Lake Tahoe. Clim Change 76:121-148

Cohen S (1990) Bringing the global warming issue closer to home: the challenge of regional impact studies. Bull Am Meteorol Soc 71:520-526

Cooke RU, Reeves RW (1976) Arroyos and environmental change in the American Southwest. Oxford University Press, New York, $226 \mathrm{pp}$

Dettinger MD, Cayan DR (1995) Large-scale atmospheric forcing of recent trends toward early snowmelt runoff in California. J Clim 8:606-623

Dettinger MD, Cayan DR, Knowles N, Westerling A, Tyree M (2004) Recent projections of 21st-century climate change and watershed responses in the Sierra Nevada. USDA Forest Service Gen Tech Rep PSW-GTR-193, pp 43-46

Dobrowski SAJ, Greenberg J, Schladow G (2009) How much influence does landscape-scale physiography have on air temperature in a mountain environment? Agric For Meteorol 49:17511758

Flanner M, Zender C, Randerson J, Rasch P (2007) Present-day climate forcing and response from black carbon in snow. J Geophys Res 112:D11202. doi:10.1029/2006JD008003

Hamlet AF, Mote PW, Clark MP, Lettenmaier DP (2005) Effects of temperature and precipitation variablility on snowpack trends in the Western United States. J Clim 18:4545-4561

Hansen J, Nazarenk L (2004) Soot forcing via snow and ice albedos. Proc Natl Acad Sci 101:423-428

Helsel DR, Frans ML (2006) Regional Kendall test for trend. Environ Sci Technol 40:4066-4073

Helsel DR, Hirsch RM (1995) Statistical methods in water resources. Elsevier, New York

Helsel DR, Mueller DK, Slack JR (2005) Computer program for the Kendall family of trend tests. US Geol. Surv. Scientific Investigations Rep. 2005-5275, Reston, VA, 4 pp. http://pubs.usgs.gov/ sir/2005/5275/

IMPROVE (2009) Data resources. Interagency monitoring of protected visual environment. http://vista.cira.colostate.edu/IMPROVE/. Accessed 21 Jan 2009

Jassby AD, Goldman CR, Reuter JE, Richards RC (1999) Origins and scale dependence of temporal variability in the transparency of Lake Tahoe, California-Nevada. Limnol Oceanogr 44: 282-294

JISAO (2008) The Pacific decadal oscillation. Joint Institute for the Study of the Atmosphere and Environment. http://jisao.washington.edu/pdo/. Accessed 16 Sept 2008

Johnson CM, Needham PR (1966) Ionic composition of Sagehen Creek, California following an adjacent fire. Ecology 47:636-639 
Johnson T, Dozier J, Michaelsen J (1999) Climate change and Sierra Nevada snowpack. In: Interactions between the cryosphere, climate and greenhouse gases. Proc. IUGG 99 Symp. HS2, IAHS, Birmingham, pp 63-70

Kalnay E, Cai M (2003) Impact of urbanization and land-use change on climate. Nature 423:528-531

Kamerath M, Chandra S, Allan B (2008) Distribution and impacts of warm water invasive fish in Lake Tahoe. Aquatic Invasions 3:35-41

Karl TR, Williams CN (1987) An approach to adjusting climatological time series for discontinuous inhomogeneities. J Clim Appl Meteorol 26:1744-1763

Karl TR, Williams CN Jr, Young PJ, Wendland WM (1986) A model to estimate the time of observation bias associated with monthly mean maximum, minimum and mean temperatures for the United States. J Clim Appl Meteorol 25:145-160

Karl TR, Diaz HF, Kukla G (1988) Urbanization: its detection and effect in the United States climate record. J Clim 1:1099-1123

Kattelmann R (1991) Peak flows from snowmelt runoff in the Sierra Nevada, USA. In: Snow Hydrology and Forests in High Alpine Areas, IAHS, Vienna, pp 203-211

Kim J (2005) A projection of the effects of the climate change induced by increased $\mathrm{CO}_{2}$ on extreme hydrologic events in the western U.S. Clim Change 68:153-168

Knowles N, Cayan D (2004) Elevational dependence of projected hydrologic changes in the San Francisco estuary and watershed. Clim Change 62:319-336

Knowles N, Dettinger M, Cayan D (2006) Trends in snowfall versus rainfall in the western United States. J Clim 19:4545-4559

LaDochy S, Medina R, Patzert W (2007) Recent California climate variability: spatial and temporal patterns in temperature trends. Clim Res 33:159-169

Lobell D, Bonfils C (2008) The effect of irrigation on regional temperatures: a spatial and temporal analysis of trends in California, 1934-2003. J Clim 21:2063-2071

Mantua NJ, Hare SR, Zhang Y, Wallace JM, Francis RC (1997) A Pacific interdecadal climate oscillation with impacts on salmon production. Bull Am Meteorol Soc 78:1069-1079

Mote PW, Hamlet AF, Clark M, Lettenmaier D (2005) Declining mountain snowpack in western North America. Bull Am Meteorol Soc 86:19-49

National Climate Data Center (2008) System access-MMS. http://mi3.ncdc.noaa.gov/mi3_access. Accessed 16 Sept 2008

Ngai KLC (2008) Potential effects of climate change on the invasion of largemouth bass (Micropterus salmoides) in Lake Tahoe, California-Nevada. MS Thesis, Graduate Dept. of Zoology (118 pp). University of Toronto, Toronto, Canada

NOAA (2008). Multivariate ENSO Index (MEI). Earth System Research Laboratory. http://www. cdc.noaa.gov/people/klaus.wolter/MEI/mei.html. Accessed 16 Sept 2008

Pierce DW, Barnett TP, Hidalgo H, Das T, Bonfils C, Santer B, Bala G, Dettinger M, Cayan D, Mirin A, Wood A, Nozawa T (2008) Attribution of declining western U.S. snowpack to human effects. J Clim 21:6425-6444

Qian Y, Gustafson W, Leung LR, Ghan S (2009) Effects of soot-induced snow albedo change on snowpack and hydrological cycle in western U.S. based on weather research and forecasting chemistry and regional climate simulations. J Geophys Res 114:DO3108. doi:10.1029/ 2008JD011039

Oreskes N (2004) The scientific consensus on climate change. Science 306:1686

Redmond K (1991) Effects of time of observation bias on temperature time series. Conference on Applied Climatology (6 pp). Salt Lake City, UT

Redmond K (1992) Effects of observation time on interpretation of climatic time series-a need for consistency. In: Redmond KT (ed) Eighth Annual Pacific Climate (PACLIM) Workshop, pp 141-150. California Dept. Water Resour Interagency Ecological Studies Program for the Sacramento-San Joaquin Estuary, Asilomar CA

Regonda S, Rajagopalan B, Clark M, Pitlick J (2005) Seasonal cycle shifts in hydroclimatology over the western United States. J Clim 18:372-384

Roos M (1991) A trend of decreasing snowmelt runoff in northern California. 59th Western Snow Conference, pp 29-36. Western Snow Conf, Juneau AK

Rouse WR, Oswald CJ, Binyamin J, Spence C, Schertzer W, Blanken P, Bussieres N, Duguay C (2005) The role of northern lakes in a regional energy balance. J Hydrometeorol 6:291-305

Running S (2006) Is global warming causing more, larger wildfires? Sci Express 313:927-928

Schladow SG (ed) (2009) Tahoe: state of the lake report 2009. UC Davis Tahoe Environmental Research Center Technical Report, Davis, CA 
Snyder MA, Sloan LC (2005) Transient future climate over the western United States using a regional climate model. Earth Interact 9(11):1-21

Stewart IT, Cayan D, Dettinger M (2004) Changes in snowmelt runoff timing in western North America under a 'business as usual' climate change scenario. Clim Change 62:217-232

Stewart IT, Cayan DR, Dettinger M (2005) Changes toward earlier streamflow timing across western North America. J Clim 18:1136-1155

Tollefson J (2009) Climate's smoky spectre. Nature 460:29-32

Trenberth KE (1984) Some effects of finite sample size and persistence on meteorological statistics. Part I: autocorrelations. Mon Weather Rev 112:2359-2368

van Belle G, Hughes J (1984) Nonparametric tests for trend in water quality. Water Resour Res 20:127-136

von Storch H (1999) Misuses of statistical analysis in climate research. In: von Storch H, Navarra A (eds) Analysis of climate variability. Springer-Verlag, New York, pp 11-26

Westerling AL, Hidalgo HG, Cayan DR, Swetnam T (2006) Warming and earlier spring increases western U.S. forest wildfire activity. Sci Express 313:940-943

Western Regional Climate Center (2008) Historical climate information. http://www.wrcc.dri.edu. Accessed 16 Sept 2008

Williams CN Jr, Menne MJ, Vose RS, Easterling DR (2008) Long-term daily and monthly climate records for stations across the contiguous United States. http://cdiac.ornl.gov/epubs/ndp/ ushcn/newushcn.html. Accessed 16 Sept 2008

Winder M, Reuter JR, Schladow SG (2009) Lake warming favors small-sized planktonic diatom species. Proc R Soc B 276:427-435 